\title{
The future of farming: Who will produce our food?
}

\author{
Ken E. Giller ${ }^{1}$ (D) - Thomas Delaune ${ }^{1}$ (D) - João Vasco Silva ${ }^{1,2}$ (D) Katrien Descheemaeker ${ }^{1}$ (D) $\cdot$ Gerrie van de Ven $^{1}$ (D) \\ Antonius G.T. Schut ${ }^{1}$ (D) - Mark van Wijk ${ }^{3}$ (D) - James Hammond ${ }^{3}$ (D) $\cdot$ Zvi Hochman $^{4}$ (D) - Godfrey Taulya ${ }^{5}$ (D)

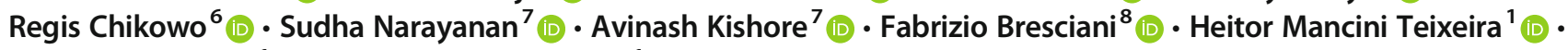 \\ Jens A. Andersson ${ }^{1}$ (D) $\cdot$ Martin K. van Ittersum ${ }^{1}$ (D)
}

Received: 22 March 2021 / Accepted: 11 June 2021 / Published online: 3 September 2021

(C) The Author(s) 2021

\begin{abstract}
Achieving SDG2 (zero hunger) in a situation of rapid global population growth requires a continued focus on food production. Farming not merely needs to sustainably produce nutritious diets, but should also provide livelihoods for farmers, while retaining natural ecosystems and services. Rather than focusing on production principles, this article explores the interrelations between farms and farming systems in the global food system. Evaluating farming systems around the world, we reveal a bewildering diversity. While family farms predominate, these range in size from less than 0.1 ha to more than 10,000 ha, and from hand hoe use to machine-based cultivation, enabling one person to plant more than 500 ha in a day. Yet, farming in different parts of the world is highly interdependent, not least because prices paid for farm produce are largely determined by global markets. Furthermore, the economic viability of farming is a problem, globally. We highlight trends in major regions of the world and explore possible trajectories for the future and ask: Who are the farmers of the future? Changing patterns of land ownership, rental and exchange mean that the concept of 'what is a farm' becomes increasingly fluid. Next to declining employment and rural depopulation, we also foresee more environmentally-friendly, less external input dependent, regionalised production systems. This may require the reversal of a global trend towards increasing specialisation to a recoupling of arable and livestock farming, not least for the resilience it provides. It might also require a slow-down or reversal of the widespread trend of scale enlargement in agriculture. Next to this trend of scale enlargement, small farms persist in Asia: consolidation of farms proceeds at a snail's pace in South-east Asia and 70\% of farms in India are 'ultra-small' - less than 0.05 ha. Also in Africa, where we find smallholder farms are much smaller than often assumed $(<1$ ha), farming households are often food insecure. A raft of pro-poor policies and investments are needed to stimulate small-scale agriculture as part of a broader focus on rural development to address persistent poverty and hunger. Smallholder farms will remain an important source of food and income, and a social safety net in absence of alternative livelihood security. But with limited possibilities for smallholders to 'step-up', the agricultural engine of growth appears to be broken. Smallholder agriculture cannot deliver the rate of economic growth currently assumed by many policy initiatives in Africa.
\end{abstract}

Keywords Population growth $\cdot$ Food security $\cdot$ Yield gaps $\cdot$ Smallholder farms $\cdot$ Sustainable intensification

\section{Introduction}

Achieving global food and nutrition security demands a global approach to food systems. All four pillars of food and nutrition

This article belongs to the Topical Collection: Food System Transformations for Healthier Diets, Inclusive Livelihoods and Sustainable Environment Guest Editors: Romina E Cavatassi, Leslie Lipper, Ruerd Ruben, Eric Smaling, Paul Winters

Ken E. Giller

ken.giller@wur.nl

Extended author information available on the last page of the article security must be addressed: availability, access, utilization and stability to ensure that the basic human right to food is met for everyone. This is the challenge set by Sustainable Development Goal 2: End hunger, achieve food security and improved nutrition, and promote sustainable agriculture (United Nations, 2015). There is consensus that food production must increase to meet global needs, that adjustments in diets are required to ensure efficient use of food to avoid undernutrition and obesity, that the expansion of land under agriculture should be avoided, and that food should be produced in a sustainable way. Global population growth continues apace with most recent estimates of 9.4-10.1 billion by 2050 and an extra $0-2.7$ billion people by 2100 (United 
Nations, 2019). A recent study presents a more optimistic analysis in which the global population will peak at 9.7 billion people in 2064 and decline to 8.8 billion by 2100 (Vollset et al., 2020). Even with these revised calculations the population of sub-Saharan Africa will reach 3.1 billion in $2100-$ almost 2.5 times what it is now. Thus, there is no doubt that global and in particular regional food production must increase to meet the future demand of the growing population - but by how much? Where in the world will it be produced? And above all - who are the farmers of the future who will produce the food to feed us all? These are the questions that we address in this review.

Questions about the future of farming are often framed around the need to reform 'conventional' agriculture around the principles of agroecology, organic agriculture and (increasingly) regenerative agriculture (Giller et al., 2021). Leading reports conclude that the food system faces a crisis of the sustainability of agriculture, land use, and degradation of the environment (e.g. Springmann et al., 2018). Rather than reviewing and repeating published analyses, we draw attention to a different, less-frequently mentioned crisis: the crisis in the economic and social sustainability of (family) farming. A major challenge for agricultural policy across the globe is how to maintain and increase the viability of a variety of farms with different scales of operation.

Smallholder production is estimated to account for 50 $70 \%$ of global food production: smallholders play a crucial role in food systems (see section 2 below). We face an ironic and invidious situation where many smallholder households are food insecure themselves. This is a particularly acute, double pronged problem in lower-income countries where smallholder farms are key to both their own food security and to economic development. This is especially true in sub-Saharan Africa. We therefore focus particularly on (future) developments in Africa, where food is produced overwhelmingly on smallholder farms, where the growth of population and food demand is most rapid, and where agricultural transformation appears to be most urgent.

Our paper opens with an update (section 2) of projections of future global food demand, where we highlight the major global food sources (exporting countries) and sinks (importing countries). We then review major trends in agriculture in different regions (in section 3). This review is used to identify major commonalities and differences across the globe (section 4) and to inform a discussion on the future of farming (section 5), and particularly smallholder farming in Africa. Our review of agricultural development across the global does not imply we expect agricultural development in Africa to follow a similar path as observed on (any) other continent(s). However, options for agricultural intensification in Africa have to be considered in the context of a globalised food system. Given that international trade in the basic food commodities is key to the functioning of the global food system, we cannot understand the opportunities, challenges and future prospects of smallholder farmers in isolation. For this reason highlighting pathways of development followed by agriculture in other parts of the world, who compete on the world market and local markets with smallholders on what can hardly be considered a level playing field.

We conclude by returning to the question as to what does the future of farming look like from the perspective of global food and nutrition security? And what does that future perspective hold for the millions of rural households who inevitably will continue to depend, at least partly, on agriculture? In Africa, it seems that the sustainable intensification of agriculture has been foreclosed by land fragmentation and a lack of alternatives outside agriculture. The need for more regionalised, environmentally-friendly agricultural productions systems, and better shielding of smallholder farmers against the vagaries of globalised markets, implies the need for major policy shifts: away from globalised free trade agreements, and instead towards strengthened local and regional agricultural production systems.

\section{Revisiting the need to increase global food production}

Studies on future global food production and global food security generally take as a premise that global demand for food will increase by $60 \%$ between 2005/2007 (the base period) and 2050 (Alexandratos \& Bruinsma, 2012), and that the global crop demand may increase by $100-110 \%$ over the same period (Tilman et al., 2011). Yet, "projections are often simplified into a goal of doubling yields, which serves as an urgent rallying cry for research, policy, and industry" (Hunter et al., 2017). The premises and assumptions that are commonly used in projections of future global demand for food need to be challenged for a number of reasons (Hunter et al., 2017).

First, the increase in food demand projected by the FAO is expressed in a monetary value which has widely contrasting implications for different food items and agricultural commodities. Second, the baseline used by Alexandratos and Bruinsma (2012) is over 10 years old. Third, projections of population increase, economic growth and income increase (the main drivers of future food demand) need continuous update: for instance, global population projections for the year 2050 have increased since 2005/2007 from ca. 9.1 billion to 9.8 billion (United Nations, 2019). Fourth, demand increases are directly converted into production increases on the basis of current consumption patterns and their current links with gross domestic product (GDP): accumulating and compelling evidence (earth system boundaries, human health) shows that both production and consumption must be altered, particularly in developed nations (Hunter et al., 2017; Springmann et al., 
2018; Muller et al., 2017; Willett et al., 2019). Fifth, current grain demands are strongly determined by meat consumption patterns, which are likely to change with dietary shifts and advances in nutritious and healthy meat alternatives (Rubio et al., 2020; Parodi et al., 2018; Alexander et al., 2017). Sixth, the projections are for the globe as a whole, but play out very differently for individual continents and regions. For instance, Europe will face a decreasing population, which is also ageing, and with increasing awareness for human health issues associated with unbalanced nutrition. van Ittersum et al. (2016) make the case that regional targets for increases in production are probably more meaningful and relevant than global targets. They estimate that cereal demand in subSaharan Africa (SSA) will increase by a factor of 3.4 between 2010 and 2050 due to rapid population growth and expected changes in diets.

Based on these arguments, and the different assumptions used regarding future economic growth rates and changes in diets, estimates of the agricultural production increase required to meet global demand by 2050 range from $25 \%$ to 70\% (Hunter et al., 2017). Countries in Australasia, parts of Europe and Central Asia, North and South America are global food sources (Clapp, 2017). Given their slow growing or declining populations, the expected shifts in diets and the focus on large-scale, commercial farming, it is likely that they will continue to be major food exporters in future. Other countries, notably those in sub-Saharan Africa, will probably remain food sinks, because the rate of population growth will almost certainly outstrip the required increases in agricultural productivity for self-sufficiency (van Ittersum et al., 2016).

The question of 'who produces our food', and more specifically what contribution smallholder farmers make to global food security, has been the focus of a series of recent papers. Ricciardi et al. (2018) concluded that smallholders produce $30-34 \%$ of global food supply on $24 \%$ of global cropland area, in contrast to Samberg et al. (2016) who indicate that smallholder farming is responsible for $41 \%$ of total global calorie production, and $53 \%$ of the global production of food calories for human consumption. Herrero et al. (2017) use different farm size thresholds and conclude that globally, small and medium farms ( $\leq 50$ ha) produce $51-77 \%$ of nearly all commodities and nutrients. They also conclude that very small farms $(\leq 2 \mathrm{ha})$ are important and have local significance in sub-Saharan Africa, Southeast Asia, and South Asia, where they contribute about $30 \%$ of most food commodities, although this would be much more in the case of rice. The studies use different methods, however, both Ricciardi et al. (2018) and Herrero et al. (2017), and many other global agricultural production studies, rescale their national agricultural production numbers using the same FAOSTAT national agricultural statistics thereby forcing their numbers through the same 'eye of the needle', the reliability of which is debatable. Yet, it is widely recognised that there is large uncertainty in current crop distribution maps, together with a wide uncertainty of actual production and yield estimates, especially in low and middle income countries. Thus, although the role of smallholder farmers in food production is undoubtedly important, the precise contribution of small farms to global food security is uncertain.

\section{Trends in farming around the world}

Major trends in farming can be identified based on the primary resources for agriculture: land, labour and investment capital (Fig. 1, van Vliet et al., 2015). We distinguish two main pathways by which the economic size of a farm may increase. We use the term intensification to represent situations where capital investment in technology is used to increase output without, or with only a small increase, in the physical footprint of farming. Where land is scarce and major capital investment possible, intensification drives production of high value crops, horticulture or intensive livestock production. The term expansion is used to describe situations where capital investment in inputs and technology, often through machinery for crop establishment and harvest, allows large increases in physical farm size. In regions where land and capital for investment are relatively abundant, such as Australia, North and South America, we witness a continued expansion of farms, largely at the expense of other farms. Advances in mechanisation mean that precision agriculture can be

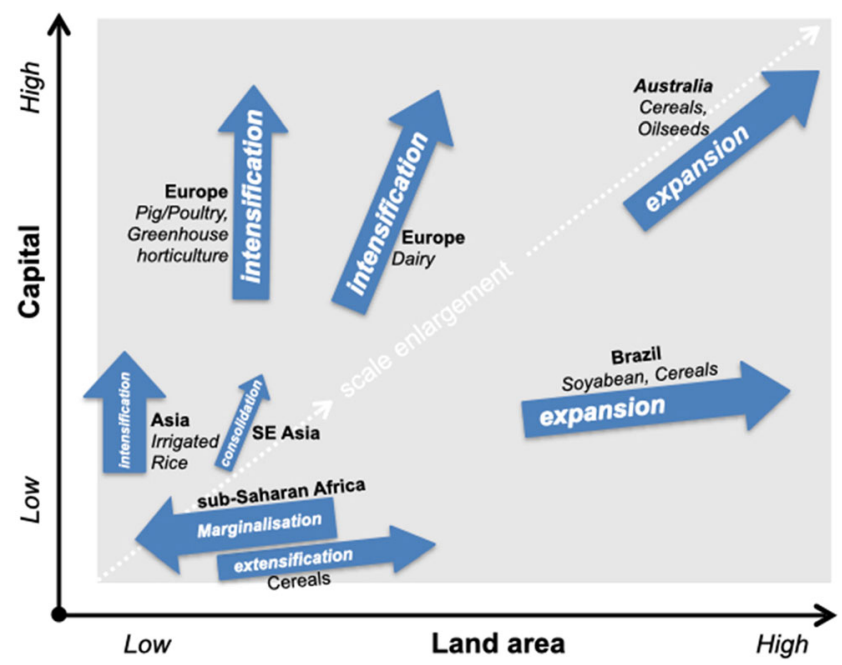

Fig. 1 Farm diversity and development trajectories in relation to the availability of capital and land. Options to increase the economic size of farms include intensification and expansion. In case of decreasing availability of land and/or capital, marginalisation occurs. As capital is generally available in developed and lacking in developing regions (Hazell et al., 2010), these are depicted in the upper and lower parts of the figure. Intensification and expansion often go hand in hand with specialisation, which is not explicitly captured in the figure (Modified from van Vliet et al. 2015) 
practised on farms of 5-10,000 ha often managed by only few individuals.

In less-developed countries very different trends are observed. In the case of 'extensification', the physical farm size expands without accompanying increases in inputs or technology - a case where poor yields prevail but are compensated by an increase in the land area cultivated. Sub-division of farms due to population growth leads to fragmentation of land into small and uneconomic units, often resulting in marginalisation. In this section we examine each of these trends in turn.

\subsection{Expansion of farms in Australia}

Australia presents a relevant example to compare with Africa as these two continents share some agroecological characteristics in terms of climate and soils (van Wart et al., 2013). So, can Australia provide insights as to what is possible when capital is not constrained?

Currently, about 85,000 Australian farms manage 58\% of Australian land. They produce $2.2 \%$ of gross domestic product, $11 \%$ of goods and services exports (Australia exports around $70 \%$ of the total value of agriculture, fisheries and forestry production) and directly employ $2.6 \%$ of the workforce. The value of agriculture, fisheries and forestry production, at around AUD 69 billion, increased by $19 \%$ in real terms over the 20 years to 2018-2019 (Jackson et al., 2020).

The mix of Australian agricultural activity is determined by climate, water availability, soil type and proximity to markets. Livestock grazing is widespread, occurring in most areas of Australia (with 345 million hectares grazing on native vegetation) while cropping (29 million hectares) and horticulture (0.53 million hectares) are generally concentrated in areas relatively close to the coast (ABARES - BRS 2010; ABARES, 2016). The average farm size of 4331 ha is skewed by the very large cattle grazing properties in the northern rangelands where, as an extreme example, Australia's largest cattle station, Anna Downs, is 24,000 sq. km yet only stocks around 10,000 head. However, farm size does matter: large farms have grown from around $3 \%$ to around $15 \%$ of the total number of farms over the last four decades, while their share of output has increased from $25 \%$ to around $58 \%$ of the value of output (Jackson et al., 2020). Ninety-seven per cent of Australian farms (and $86 \%$ of agricultural land) are family owned. The rest are either vertically integrated with supply chain operations or else owned by non-farm equity investors.

\subsection{Intensification and specialisation of farming in North-West Europe}

Recent trends in European agriculture are tied up with the development of the European Union in the 1950s, its Common Agricultural Policy (CAP), and the introduction of
Green Revolution technologies (Oskam et al., 2011). Making strong use of price support and market protection, the CAP was established to ensure self-sufficiency of major food products, stable prices of food and other agricultural products for consumers and producers and regional agricultural development.

The strong development in agricultural productivity was an important stepping stone that supported mechanisation and increasing wages of agricultural labourers as well as growth in employment in the industrial and service sectors. This led to a process of intensification and specialisation of farming (Abson, 2019) which further drove down costs and stimulated productivity in terms of land, capital and especially labour as an increasingly expensive production factor. Farming became more capital-intensive and mechanized, which went hand in hand with specialisation and scale enlargement (e.g. Fig. 2), driven by economies of scale (Oskam et al., 2011; Abson, 2019). Specialisation is exemplified by a strong decrease in the number and share of mixed farms that combine arable and livestock farming (Schut et al., 2020; Garrett et al., 2020), concentration around a limited number of (high-value) crops, and regional specialisation (e.g. horticulture, chicken production) together with dedicated support services.

The economic benefits of scale are substantial and are made possible by advances in technology including mechanisation and robotics, and availability of relatively cheap finance, while the price of labour has increased. Yet, despite the trends of specialisation and upscaling, farmers' incomes in Europe are under high pressure, especially for smaller farms. Nominal prices of agricultural products have been decreasing (Koning \& van Ittersum, 2009), whereas the costs have not reduced concomitantly due to the need to continuously invest in new technology, buildings and land. Farm incomes are substantially less than the average income of all professions, in particular in richer countries, even with an important share of the income provided through EU subsidies (Fig. 3).

Increasing farm sizes and limited land availability, particularly in North-West Europe, resulted in decreasing numbers of farms and in negative effects on rural jobs, livelihoods and services. It also resulted in massive overproduction, an increasingly costly CAP and spill-over effects in terms of negative impacts on the environment. In the 1990s, these developments led to a series of reforms of the CAP and a shift in focus from agricultural intensification and production to other objectives, such as rural development, environmental protection and nature conservation. Price support was increasingly replaced by direct income support to farmers, with some conditions to meet 
Fig. 2 Changes in the number of milking cows per farm and the number of dairy farms in the Netherlands between 1980 and 2019. Data source: Centraal Bureau voor de Statistiek, www. cbs.nl

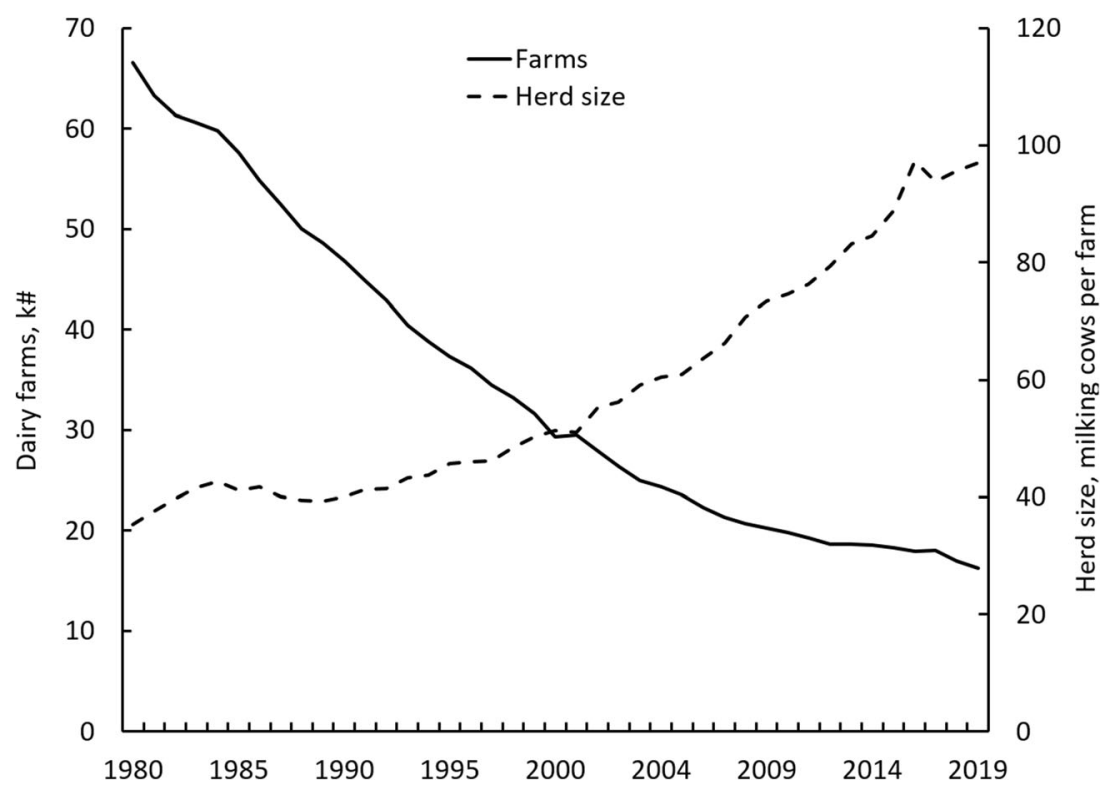

agri-environmental criteria. In parallel, environmental policies were developed: in 1991 the Nitrates Directive was introduced to control nitrate pollution and water quality. The process of introducing legislation for environmental protection and nature conservation (e.g. the Habitats Directive in 1992) took centre stage, with frameworks set by the EU and their national implementation.

More recently, societal concerns about food production, animal welfare, and as some call it, the 'industrial scale' of farming, food quality and impacts of agriculture on the environment have become more prominent. These concerns have become an additional driver of change for agriculture, either through voluntary changes by farmers or enforced through legislation. The demands of retailers and consumers are increasingly influencing the modes of production. Next to organic farming, which is still relatively small in most European countries $(8.5 \%$ of the total utilized agricultural area in 2019, EUROSTAT 2020), other alternative forms of agriculture are promoted, including agroecology, circular agriculture, urban farming and nature-inclusive agriculture, often accompanied by a range of food labels. Several of these include a drive and/or incentives to diversify the production systems or to promote a smaller scale of farming. Further, societal attention is given to a range of environmental issues - air pollution, water quality, habitat destruction, climate change - while legislation is fragmented and evolves continuously. All this results in pressures on farmers and farming in North-west Europe to adapt, invest and change continuously, while many feel that a long-term perspective of farming is lacking.

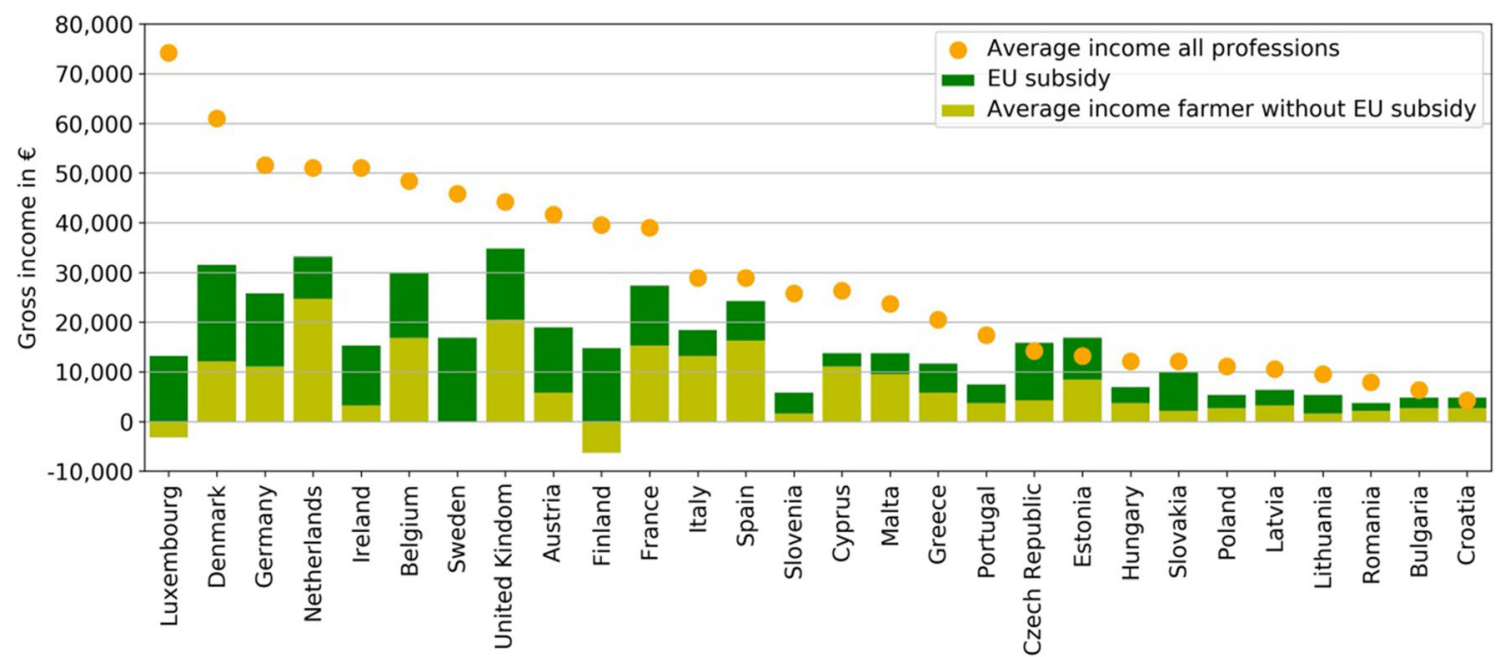

Fig. 3 Income of farmers in EU countries with and without EU subsidies in comparison with average incomes from all professions. Source: (EC, 2020) 


\subsection{Agricultural expansion and a dualist agrarian structure: Family farming and large-scale export ag- riculture in Latin America}

Despite a history of conflict over land access, popular protest, expropriation and land redistribution (Oxfam, 2016), agriculture in Latin America is still characterized by a highly unequal access to land and natural resources. Very large land properties (the so-called 'latifúndios'), ranging in size for several hundred to thousands of hectares, are concentrated in the hands of a small fraction of land owners who run farms using wage labour that dominate export-oriented production. Yet, the vast majority of Latin Americans farmers are nearly landless farm workers and family farms (FAO, 2019a; Oxfam, 2016). Although most farms across the world can be considered to be family farms (van Vliet et al., 2015), the concept has specific relevance in the Latin American context. It became increasingly popular since the end of dictatorships, as family farmers were able to strengthen their mobilization and organisation in movements, unions, associations, and cooperatives (Schneider, 2016). Moreover, many public policies and legal regulations directed to family farmers were created, with long-term programmes implemented in Brazil, Argentina, Cuba and Uruguay (Schneider, 2016). Although family farmers have been increasingly recognised for their contribution to the social, environmental and economic development of Latin American countries, they often do not fit the modernization paradigm of agriculture and have also been largely marginalized, which results in challenges such as poverty reduction, integration to markets and access to land (Medina et al., 2015). While it is estimated that $14 \%$ of all land in Latin America has changed hands through land redistribution, land negotiation or land colonization between 1930 and 2008 (FAO, 2019a), land distributions remain much more skewed than in other structurally-transformed economies, such as the United Kingdom, or other agricultural export-oriented countries, such as the Netherlands (Fig. 4). It is estimated that $1 \%$ of farms hold more than half of the total agricultural land in Latin America (Oxfam, 2016).

Aside from the political power and economic significance of large scale, export-agriculture, Latin American family farming plays a significant role in income generation and food production and security (IFAD, 2019). It is estimated that family farms represent $80 \%$ of all farms (17 million farms), occupy $35 \%$ of the cultivated land in Latin America, and provide 27-67\% of the total national production of Latin American countries (IFAD, 2019). While covering a smaller land area than largescale agriculture, family farms generate $57-77 \%$ of the total number of jobs in rural areas (Schneider, 2016).

Despite the competition for land and resources between the large-scale and family farming sectors, there is often limited overlap in terms of crop focus and competition in agricultural markets. In Brazil, where large-scale farming dominates
Fig. 4 Lorenz curves showing the cumulative share of agricultural area $(\%)$ plotted against the cumulative share of farm holdings (\%) for different countries in Latin America: Brazil (2017), Chile (2006), Colombia (2014), and Uruguay (2011). The Netherlands (2010) and the United Kingdom (2010) are included for the purpose of comparison (Source: FAO, 2019a; IBGE, 2019)

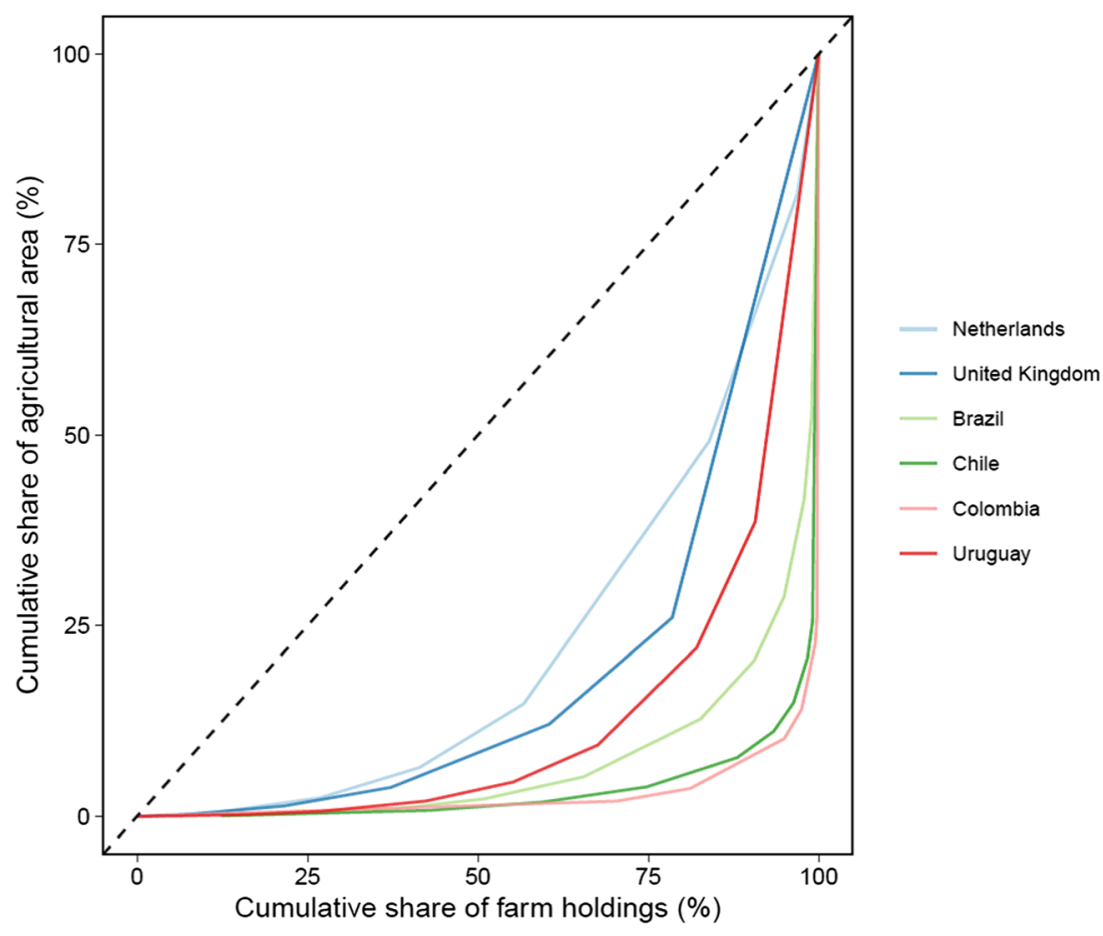


Fig. 5 Share of the total value of crop production contributed by different crops across different farm classes in Brazil (Source: IBGE, 2019) (Plant extractivism is often practiced by local and traditional communities and refers to plant products, such as wood, tea, and fruits, obtained from the management of natural ecosystems)

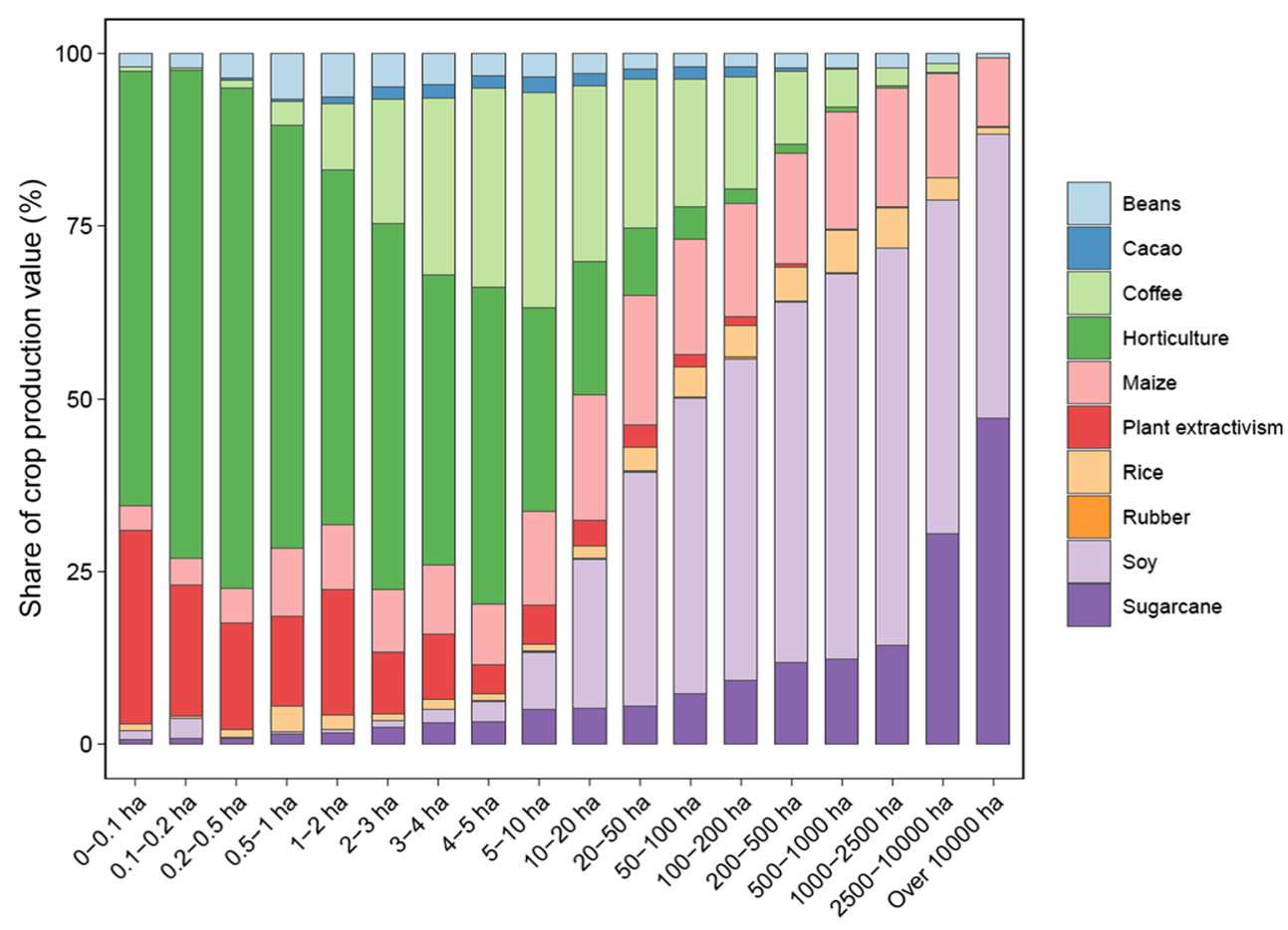

export-oriented production of sugarcane and soybean, family farming is largely responsible for the production of beans, coffee, cacao and horticultural crops (Fig. 5).

Although large-scale farming dominates export agriculture in Latin America, there are remarkable differences among countries. In countries with hilly, discontinuous terrain such as Chile, Colombia and Peru, there is a strong focus on high value and horticultural crops, such as coffee and fruits (FAO, 2020). In these countries, smaller, labour-intensive farms play a larger role in export-oriented agriculture (FAO, 2019b). By contrast, in countries with high land availability and/or high suitability for mechanization (e.g. Brazil, Argentina and Uruguay) there is a strong focus on low value, high volume field crops, such as soybean and sugarcane (FAO, 2020). The rapid expansion of soybean and sugarcane in the Cerrado and Amazon in Brazil is a response to global market demands as well as governmental incentives (Cattelan \& Dall'Agnol, 2018; de Arruda et al., 2019). Production expansion was led by technological interventions, such as (overhead) irrigation, fertilization, plant breeding and microbial inoculation, enabling cultivation in areas previously unsuited for commodity crops (Cattelan \& Dall'Agnol, 2018). Yet, the expansion of agricultural areas under large-scale monocultures is also associated with land grabbing, expropriation and conflicts with local communities (Eloy et al., 2016; Sauer, 2018), biodiversity loss (Barona et al., 2010; Rausch et al., 2019), climate change (Escobar et al., 2020; Lathuillière et al., 2014), and reduced water provision and quality (Escobar et al., 2020; Lathuillière et al., 2014; Rekow, 2019). These unprecedented externalities are critical at local and global level. They indicate the urgent need of policies, programs and regulations that focus on the use and conservation of biodiversity and natural resources in agriculture, as well as on the rights and well-being of local communities.

\subsection{Economic structural transformation and slow farm consolidation in China and South-east Asia}

Despite the rapid structural transformation of the Chinese and some other South-east Asian economies, agriculture in this region remains characterized by the presence of very small farms (for a comprehensive review, see Thapa \& Gaiha, 2011). In the two largest countries in the region, China and Indonesia, the average size of operational holdings is just 0.6 ha and 0.8 ha respectively (Hazell, 2013; Thapa \& Gaiha, 2011; Otsuka, 2013). This dominance of small-scale farming in the region - only the Philippines, Malaysia and Indonesia have substantial plantation sectors and policy support for their development- is the result of land fragmentation driven by population growth on fertile lands. Although smallholder farms remain dominant, economic structural transformation in South-east Asia has been accompanied by a steady reduction in rural poverty. Between 1990 and 2011, the extreme poverty headcount ratio (US\$1.25/day, 2005 PPP) declined from $46 \%$ to $12 \%$. However, in most of East and South-east Asia's extreme poverty remains concentrated in rural areas (IFAD, 2019).

Next to reduced rural poverty, economic structural transformation is also visible in changes in agricultural production. In response to growing incomes and urbanization and the 
associated dietary changes, the share of cereal production has steadily declined - in China from nearly $40 \%$ in the 1990s, to about $20 \%$ two to three decades later - while production of livestock and high value crops has increased. For instance, in Indonesia, Myanmar, and Thailand, the expansion of industrial (e.g. oil palm, and rubber) and beverage (cacao, coffee, and tea) crops, resulting from strong policy support, has driven the transformation of significant parts of their agricultural sector.

Increasing rural wages represent a strong stimulus for mechanization and labour productivity enhancing technologies and crops. Yet, the average size in Asia hardly increases (in China from 0.55 ha to 0.6 ha between 2000 and 2010). To understand this slow growth in average farm sizes in situations of rising rural wages and (projected) decreasing rural populations, a focus on the process of farm consolidation may be useful. Rural out-migration and increasing rural wages are triggering investments in expanded farm operations through increased land renting and farm mechanization (Wang et al., 2014; Yamauchi, 2014). Smallholders with relatively larger holdings and cooperatives appear to drive this slow consolidation process. Policy initiatives to achieve land consolidation, such as those in Japan (Otsuka et al., 2016; Kuo, 2014; Seo, 2014), have met with only limited success. Farm consolidation, mechanization and increased labour productivity in agriculture will play an increasing role in the policy agenda of China and South-east Asia given the paramount concern of ensuring that food production remains competitive internationally.

Countries such as China, Vietnam, Myanmar and the Philippines have all enacted land policies with the objective of improving tenure security (of state-owned land) and land (rental) markets (Gao et al., 2012; Pingali \& Xuan, 1992). In addition, since 2000, more governments have followed Japan and South Korea, establishing agricultural protection policies to sustain farm incomes while keeping the cost of food production in check. Price policies, food trade restrictions and agricultural input subsidies have resulted in higher public expenditure on agriculture, but as agriculture's share in GDP diminishes, efficiency losses from protection become more diluted among consumers and taxpayers (Hayami, 2007). As a result, the demand for protection tends to find less resistance among policy makers concerned with the growing income gap between rural and urban areas.

\subsection{South Asia: The persistence of small-scale farming in India}

India, like its South Asian neighbours, is often considered a nation of smallholders that seems to have escaped the trend towards farm consolidation (Eastwood et al., 2010). Small farms in India are defined as holdings less than 2 ha and operational holdings greater than 10 ha are classified as "large". Between 1990-91 and 2015-16, the share of operational holdings larger than 4 ha has halved from $8.8 \%$ to $4.4 \%$ whereas the share of those considered small and marginal (with $<2$ ha) rose from 78 to $86 \%$. 'Ultra-small' farms predominate: $71.7 \%$ of holdings had less than 0.05 ha. This shrinking size of land holdings is partly an outcome of subdivision of property across generations, but also of India's policies. Imposed ceilings on land ownership, ownership transfer restrictions, and land reforms (like in Kerala and West Bengal), have favoured land ownership for smallholders over consolidation. Although there have been land reform programmes aimed at consolidation (see Oldenburg, 1990, for example) these have had limited impact on the larger trends. The persistence of smallholders in India is, however, also an outcome of the country's particular pattern of economic transformation: while agriculture's contribution to GDP has fallen to around $14 \%$, about $50 \%$ of the workforce continues to partially rely on agriculture for their livelihoods (GoI, 2018; Jodhka \& Kumar, 2017). Although the price of land increases (Chakravorty, 2013; Vijayabaskar \& Menon, 2017), most smallholders hold on to their very small plots as a fall-back (Jakimow et al., 2013). This has caused a burgeoning population of rural people who are functionally landless, more aptly described as 'landed labour.'

For these Indian smallholders operating less than 1 ha, incomes from farm and poorly paid off-farm activities do not cover household expenditure and smallholders' indebtedness appears to be symptomatic of an underlying rural crisis (Reddy \& Mishra, 2009; Vasavi, 2012; GoI, 2016, 2014a, 2014b). Agriculture no longer offers the mainstay of farming households' livelihoods and $32 \%$ of these households' incomes is derived from wage income. Today, rural is no longer synonymous with agriculture and many households depend on pluri-activities, including (circular) labour migration. Whether such incomes are reinvested in agriculture or in acquiring the skills or education for jobs in order to exit agriculture is a moot point (Vijayabaskar et al., 2018).

The current terms of trade are against agriculture - rising input costs and stagnating output prices coupled with low yields make for low returns. Rural households in a number of states experience negative growth in real net incomes (Kumar et al., 2020). Productivity growth in field crops appears to have stagnated owing to a combination of poor soils, water constraints and unbalanced fertilizer use. The current crisis in Indian agriculture is often attributed to a historical policy that privileged self-sufficiency over sustainability (Kumar et al., 2020). The Green Revolution - the rapid increase in yields - in wheat and rice was enabled by a system of procurement of food grains at a guaranteed support price with subsidies on fertilizer and electricity (for irrigation). This entrenched system of input subsidies and price support has encouraged an overwhelming dominance of rice and wheat in the production basket with a mounting fiscal burden of these subsidies. Combined with skewed input subsidy policies 
for fertilizers, energy and water, these have led to unbalanced use of fertilizers and depletion of groundwater resources (Mukherji, 2020; Shah et al., 2012). The combination of government procurement and input subsidies was eminently effective in increasing food grain production, but is now deemed to have outlived its usefulness.

Yet, the space for change in food policy is very limited. The majority of Indians (62\% in 2011-2012) and South Asians (52.4\% in 2014) live on less than $\$ 3.20$ a day (World Bank, 2020a). Such poor households spend a large share of their total consumption expenditure on food and even a small increase in food prices has a large impact on their welfare. Indian policymakers, therefore, face the twin challenge where food prices must be affordable for its vast population of consumers (including many smallholder farmers), while the price farmers realise needs to be high enough to encourage increased production. Since India has many more consumers than farmers and most farmers are net buyers of food, food price inflation is a greater policy concern than farmers' income. As a result, despite heavy subsidies on fertilizers, electricity, and water, Indian farmers were implicitly net taxed in the 2000-2016 period (OECD, 2018). These two contradictory policy imperatives also mean that the food economy cannot be left entirely to the market. Public policies and expenditure will continue to play a vital role. The prospects of climate change put further pressure on policy makers (Dinar et al., 1998; Mall et al., 2006). Annual mean temperatures are rising, the number of extreme heat days and rainfall intensity have also risen (Mani \& Sushenjit Bandyopadhyay, 2018), and are projected to rise further (Mani \& Sushenjit Bandyopadhyay, 2018). Smallholder farmers in India have low adaptive capacities given their limited abilities to invest in new technologies that can mitigate climate risks.

Active investments in institutional innovations can improve the farmer's share in the retail price of a commodity. Whether these are achieved through collective action, investment in post-harvest and retail enterprises that are farmer owned, through direct farmer-consumer channels or state managed cooperatives, would depend largely on the local context and conditions. India offers two examples - the dairy cooperatives under Operation Flood, and more recently, a federated structure of women's Self-Help Groups under the National Rural Livelihood Mission (Pandey et al., 2019; Brody et al., 2015). While the effectiveness of these initiatives remains unknown as yet, initiatives that enable market access and the growth of employment-intensive agro-based enterprises that are small or medium-scale are crucial where nonfarm opportunities remain limited.

Despite these concerns, recent years have seen a dramatic increase in smallholder production of high value crops as of 2018-2019 the production of horticultural crops stood at 314 million tonnes (fresh weight), outstripping the historical domination of food grains which stood at 285 million tonnes (dry weight) - driven largely by rising demand from urban consumers. Livestock (predominantly dairy), fisheries and poultry are among the fastest growing segments and now contribute collectively $35.5 \%$ of the Gross Value Added at basic prices in agriculture and allied activities (GoI, 2020). There also continue to be stark differences between rainfed and irrigated agriculture, and between those with access to markets and those without (Rao et al., 2006). But as Indian agriculture remains smallholder dominated, it is clear that state support is paramount, whether in extension services, input and price subsidies, the provision of infrastructure or access to markets.

\subsection{Heterogeneous pathways of intensification, extensification and marginalisation in farming systems of sub-Saharan Africa}

Africa's rapid population growth in the twentieth century has led to the expansion of agricultural land and increased cropping intensity across the continent (e.g. Headey \& Jayne, 2014,). Yet, population pressure exhibits variation as it is correlated with agro-ecological potential (land quality, climate). Also human and livestock disease pressure, conflicts, trade history, infrastructure development and land tenure arrangements play a role. For example, human settlements and sedentary agriculture first originated in the East African highlands with their favourable climate and fertile soils. Nowadays, these areas exhibit some of the highest rural population densities in sub-Saharan Africa, reaching 499 people/ $\mathrm{km}^{2}$ in Rwanda (in 2018) with regional peaks at around 1000 people $/ \mathrm{km}^{2}$ on Mount Elgon in Uganda (World Bank, 2020b). In contrast, inherently harsh environments remain sparsely populated, with densities as low as 3 people $/ \mathrm{km}^{2}$ in Namibia or 15 people/ $\mathrm{km}^{2}$ in DRC (in 2018).

The general farming systems evolution model originating from the work of Boserup (1965) and Ruthenberg (1980) suggests that under influence of two main driving factors - population pressure and market access - farming systems intensify and land productivity increases. This intensification usually consists of (combinations of) fallow reduction, soil fertility management, mechanization of cultivation practices and crop-livestock integration, requiring labour and capital investment, and often depending on land tenure arrangements. As a result, output per ha is predicted to increase, but due to changes in prices and farm size, profit per ha and income per household does not necessarily increase as well (BinswangerMkhize \& Savastano, 2017). However, earlier signs come again to the fore that the Boserup-Ruthenberg model may not be generally applicable (Lele \& Stone, 1989), and that agricultural development can become trapped in a downward unsustainability spiral fuelled by the nexus between population, agriculture and environment (Cleaver \& Schreiber, 
1994). Over the past decades, agricultural production growth in Africa has predominantly occurred through expansion of agricultural area (Chamberlin et al., 2014; Benin, 2016, Fig. 4.1), even in very densely populated areas (Nin-Pratt, 2016). A widely described problem of slow agricultural development (e.g. Headey \& Jayne, 2014) is linked to low capital investment and limited use of agricultural inputs. Mineral fertilizer is still used at very low rates in many African countries and there is only a weak relation between population density and fertilizer use at the country level (Nin-Pratt, 2016). There are exceptions, as illustrated by a doubling of maize yields in Ethiopia in the last two decades (van Dijk et al., 2020), which is linked to the use of hybrid varieties and mineral fertilizer (Abate et al., 2015). Another reason for sluggish agricultural development is the limited use of irrigation technology (You et al., 2011). Overall, it seems that the growth in output per hectare has been largely achieved through extra labour investment. This is an unsustainable pathway, because the low use of (mineral and organic) fertilizer raises the risk of soil mining and land degradation, potentially leading to vicious cycles of marginalization.

In the following sections we address in more detail two contrasting regions to highlight and explain the heterogeneity in agricultural development pathways in sub-Saharan Africa.

\subsubsection{The East African highlands: Marginalization and intensification}

The East African highlands are characterized by favourable climate conditions, good soil fertility and a low human and livestock disease burden. As a wellstudied example (e.g. Tittonell et al., 2009), Western Kenya illustrates that although extremely high population density and good market access create the perfect drivers for Boserupian intensification, less straightforward and heterogeneous development pathways co-exist in reality. Overall, the increase in population density in this region led to farm fragmentation, while a lack of investment in land management and agricultural input use led to a decline in soil fertility. Whereas these are signs of agricultural marginalization (Muyanga \& Jayne, 2014), in the same communities, some farmers also intensified land use and were able to improve their welfare. Already from the early twentieth century agricultural land and natural resources became scarce and since the 1920 s, off-farm employment and migration were important strategies to deal with the severe land constraints (Crowley \& Carter, 2000). The arrival of improved tillage technology reduced labour peak demands in agriculture and freed up time for engaging in other, non-farm activities. People engaging in high-paying employment were able to invest in (hired) labour and technologies in their farm, with improved land management and better productivity as a result.

The Ethiopian highlands, with their wide diversity in agro-ecological conditions, also offer interesting insights in the role of population pressure in agricultural development. In the favourable climate zones of the south, the typical home garden systems traditionally combined the cultivation of enset (Enset ventricosum) for food and coffee for cash with livestock (Mellisse et al., 2018b). In the past decades, increasing population density led to farm fragmentation, resulting in unviable farm sizes. Together with market development and a changing dietary preference towards cereals as staple crops in the urbanizing areas, this transformed the farming system. In areas close to markets, farmers replaced enset and coffee with khat (Catha edulis), a narcotic crop. In more remote areas, the enset-coffee systems were replaced with cereals and vegetables. The decline in enset, coupled with the disappearance of grazing land decreased livestock herd sizes weakened the croplivestock interactions that had sustained the functioning of the system in the past (Mellisse et al., 2018b). Although more market-dependent, farmers in the new systems became more food secure and able to access a more diverse diet (Mellisse et al., 2018a). However, the danger of agricultural marginalization due to fragmentation still looms, as also in these new khat-oriented systems, the smallest, resource-poor farms are not able to meet family food needs. This shows that market developments can provide opportunities for better food security on small farms, but can come at the expense of greater inequity among farms and household exposure to market and environmental hazards.

Characterized by a drier climate, the northern Ethiopian highlands have been cultivated for centuries with cereals and pulses and are home to the grainplough complex (Westphal, 1975). Photographic evidence shows signs of environmental degradation and a severe lack of woody vegetation cover already at the end of the nineteenth century at relatively low population densities (Nyssen et al., 2014). With population densities on the rise, farmers responded by labourbased intensification with very small and decreasing returns to investment. Combined with environmental degradation and droughts, this process culminated in the food crises of the 1970-1980s (von Braun et al., 1999). Yet, since then, changes in the policy context have institutionalized the improvement of land management practices in the highlands, including protection of forests, natural areas and tree plantations, which led to a remarkable re-greening of the region by the $2010 \mathrm{~s}$ (Nyssen et al., 2014). This shows again that population pressure is not the only driver of agrarian development and that depending on the institutional context, marginalization and degradation trends are not irreversible. 


\subsubsection{The Sudano-Sahelian zone in West Africa: Intensification, extensification and stagnation}

The East-West oriented belt of the Sudanian and southern Sahelian zone in West Africa has a relatively low agroecological potential due to climatic and inherent soil fertility constraints, which is reflected in a relatively small population density. These areas are the food baskets of several WestAfrican countries and since colonial times generate a large share of export earnings through cotton production (Bingen, 1998). Also here, the general pathway of agricultural development is driven by population increase, forcing farmers to increase the area under cereal production and abandon fallowing. The expansion of the cultivated area was facilitated by the introduction of animal traction, and the integration of cropping and livestock keeping allowed the recycling of nutrients for soil fertility maintenance (de Ridder et al., 2004). A next phase in the intensification pathway took place where a conducive market and political environment facilitated the use of external inputs, such as mineral fertilizers (de Ridder et al., 2004). In Mali the parastatal cotton company (CMDT; Compagnie Malienne pour le Développement du Textile) played an important role in this intensification process since the 1960s (Tefft, 2010). Indeed, alongside the promotion of cotton, the CMDT promoted the use of ox-drawn ploughs and provided access to inputs on credit. As a result, the cropping system shifted from a system based on millet and sorghum to a rotation system in which cotton and maize receive most inputs and the cattle herds of sedentary farmers grew markedly.

Different stages and some deviations from this general pathway can be discerned in the sub-humid Sudanian zone in the South and the slightly drier southern part of the Sahelian zone, just north of the first. In the more humid zone the current low population density $\left(<40\right.$ people $\left./ \mathrm{km}^{2}\right)$ is attributed to past factors including human and animal disease pressure and depopulation during the slave raiding period (Brian, 2004). Political stability during colonial times and the promotion of cotton and groundnut production led to cropland expansion after about 1910, and land is still abundantly available (Ollenburger et al., 2016). Even though recent decades saw the increase of fertilizer application rates in association with the introduction of cotton and maize (Laris et al., 2015), crop yields have not increased. Rather, increasing food demands have been met by the expansion of cultivated land and decreasing fallow (Ollenburger et al., 2016). In this landabundant area, farmers have no incentive to intensify by increasing yields on existing land, as described also for other less densely-populated regions of Africa (Baudron et al., 2012). In the northern zone where the higher population density $\left( \pm 70\right.$ people $/ \mathrm{km}^{2}$ ) has left no land available for expansion, there are no obvious signs of intensification. In the past 20-30 years, external input use only increased during a period of strong institutional support from the CMDT, crop yields remained fairly constant and labour productivity declined (Falconnier et al., 2015). Local inheritance rules perpetuate the current system of farms being managed by several nuclear families living together, meaning that farm fragmentation and consolidation are very rare phenomena. Combined with the stagnation in agricultural productivity, the majority of farms has been 'hanging in' instead of 'stepping up' (in the sense of Dorward, 2009).

The comparative analysis across African regions illustrates that population pressure results in heterogeneous pathways of intensification, marginalization and extensification due to differences in agro-ecology, market, policy and institutions and to some extent path dependency and historical patterns. Even though agricultural intensification is far from a general trend, cases of increasing total factor productivity (Fuglie, 2018) illustrate that farming systems can transition towards more sustainable forms. However, for high population-density areas with small farm sizes, there are severe risks of widespread marginalization if current trends continue. For lower-density areas, farm fragmentation is not yet alarming, but there, continued expansion will jeopardize biodiversity, degrade ecosystem services, and aggravate social injustice.

\section{Are there common patterns in agricultural development across the world?}

\subsection{Production growth has multiple drivers, yield increase relates to GDP per capita}

Global food production increased enormously during the second half of the twentieth century, keeping pace with population growth. Different regions of the world have expanded food production along contrasting pathways (Fig. 6). Taking

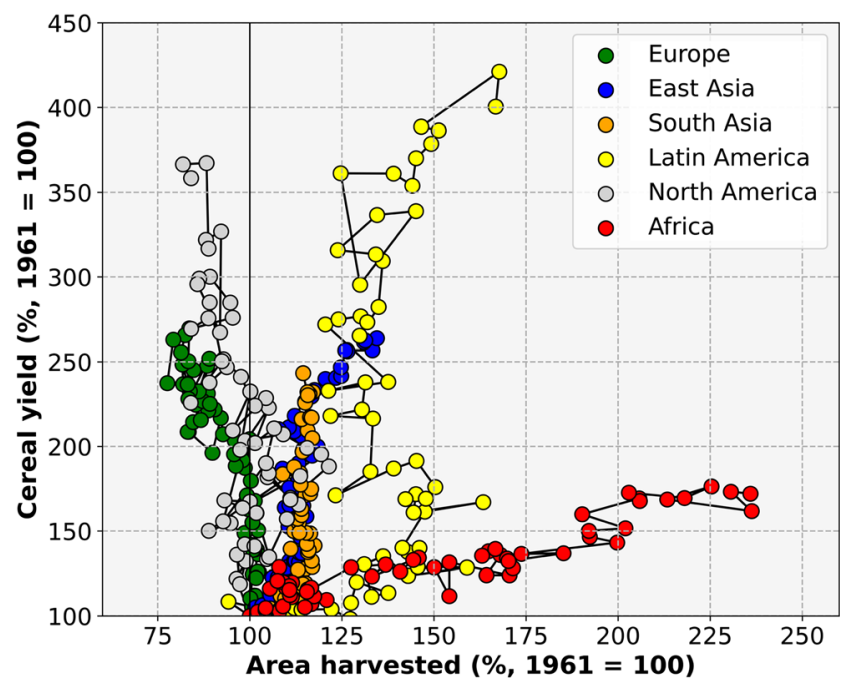

Fig. 6 Past intensification and area expansion trajectories across different regions. Data is shown in relation to the base year of 1961 (Source: FAO, 2020) 
1961 as a base year, average yields of staple cereals have increased throughout the world, but to different degrees. The strongest increases have been witnessed in Latin America where average yields are more than four-fold larger. In Europe and in (irrigated) agriculture in Asia, yields have doubled or tripled but more modest increases of around $70 \%$ have been observed in Africa. Trends in harvested area are also different, having decreased by ca. $20 \%$ in Europe, compared with increases of 60\% in Latin America, 25\% in South and Southeast Asia but close to $250 \%$ in Africa where yield growth has stagnated and area expansion has been the dominant pathway to increase production (Fig. 6).

These different trajectories as well as the prospects of future production increases are, of course, linked to differences in agricultural potential. Differences in agricultural potential and the degree to which that potential is reached by current agricultural practices, are usually expressed in terms of agroecology specific, yield potentials (Yp for irrigated and Yw for rainfed systems), actual yields (Ya), and the difference between the two: the yield gap (van Ittersum et al., 2013). An analysis in terms of yield gaps suggests a strong relation between economic development and increases in agricultural productivity; yield gaps for the major cereal crops are much wider in countries with lower GDP per capita (cf. Figs. 7 and 8). For instance, relatively small yield gaps (ca. $20 \%$ of $\mathrm{Yw}$ ) are observed for wheat in the Netherlands and for maize in the USA, while the largest yield gaps are found in rainfed cereals in countries of sub-Saharan Africa (Fig. 7, van Ittersum et al., 2016) but also in India. Only irrigation appears to blur this observed relation between yield gaps and GDP per capita. Comparing trends in yields and yield gaps across countries suggests that the Asian Green Revolution has largely occurred in irrigated agriculture. Large yield gaps persist in rainfed cereals in parts of Asia, and these are of similar magnitude to those observed in Africa (Fig. 7).

The observed large yield gaps in rainfed agriculture in both Africa and Asia suggest that there is still an enormous potential for intensification on existing agricultural land. For instance, highland banana, root and tuber crops (e.g. cassava, sweet potato, yam and Irish potato) and aroids (e.g. taro and cocoyam) are, next to cereals, important staple crops in the tropics (Tittonell \& Giller, 2013). Potential yields for highland banana in Uganda are estimated at $113 \mathrm{t}$ fresh finger yield ha ${ }^{-1}$ (Nyombi, 2010; Taulya, 2015), far more than actual yields of $7.4 \mathrm{t} \mathrm{ha}^{-1}$ in Uganda (Smithson et al., 2004). Cassava has the potential to yield $100 \mathrm{t} \mathrm{ha}^{-1}$ of fresh root within a 12-month growing season (Adiele et al., 2020), compared with national averages of $8.7 \mathrm{t} \mathrm{ha}^{-1}$ in Nigeria and $20 \mathrm{t} \mathrm{ha}^{-1}$ in Ghana (Adiele, 2020). Yet, few farmers use fertilizers on highland banana or cassava which largely explains why these yield
Fig. 7 Yields and yield gaps for rainfed wheat $(A)$, maize $(B)$ and rice $(C)$, and irrigated rice (D) across selected countries. Yield ceilings of irrigated and rainfed crops are the potential (Yp) and water-limited yields (Yw), respectively. Ya refers to actual yield. Country codes refer to iso3 codes. (Source: FAO (2020), and Global Yield Gap Atlas)
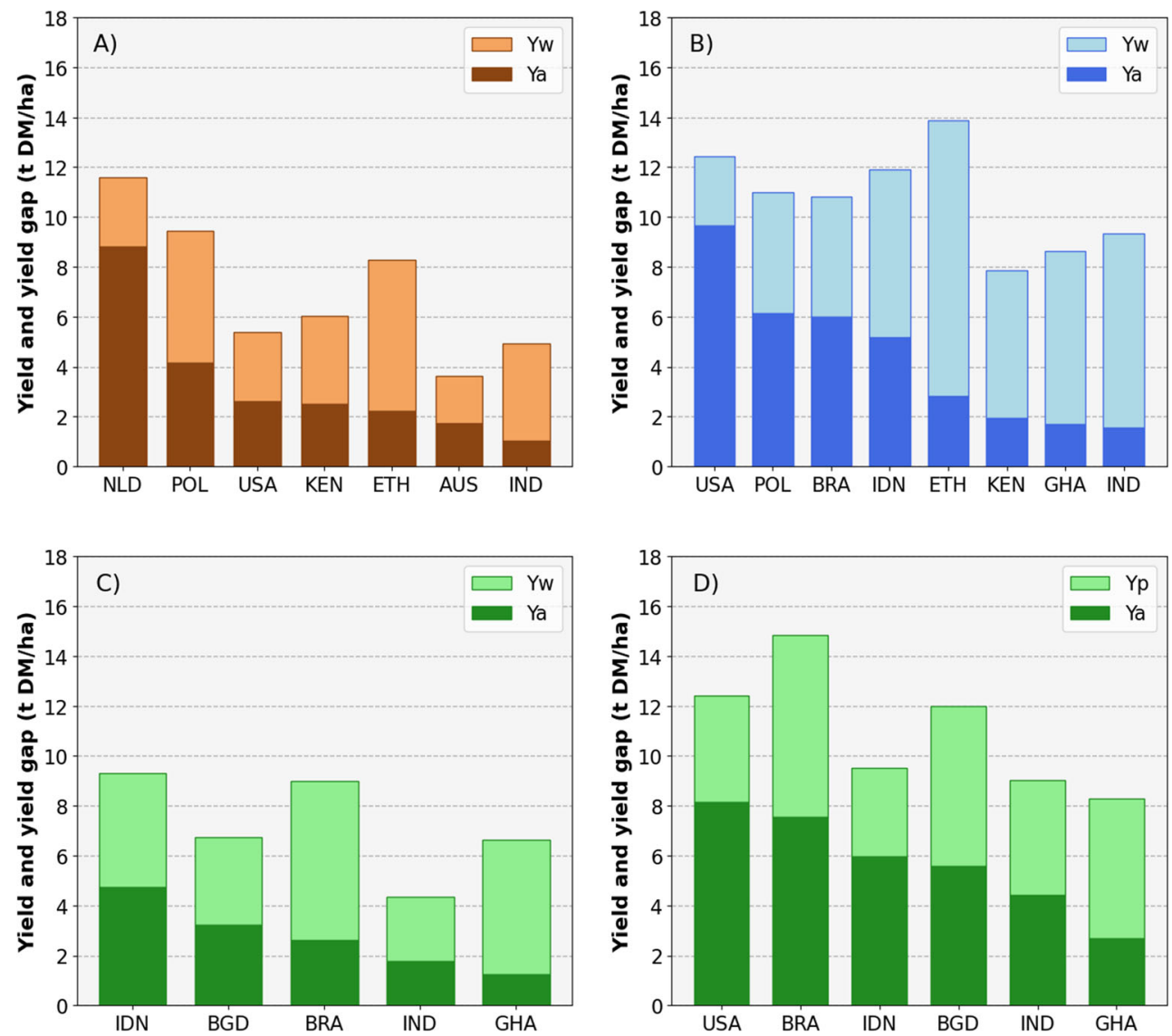
Fig. 8 Employment in the agricultural sector $(\%)$ and agricultural worker productivity (added value in USD per employee in 2016). Agricultural worker productivity is calculated as the ratio between the added value of agricultural production (USD) and the number of employees in the agricultural sector (Source: World Bank, 2020b; International Labour Organization, 2020)

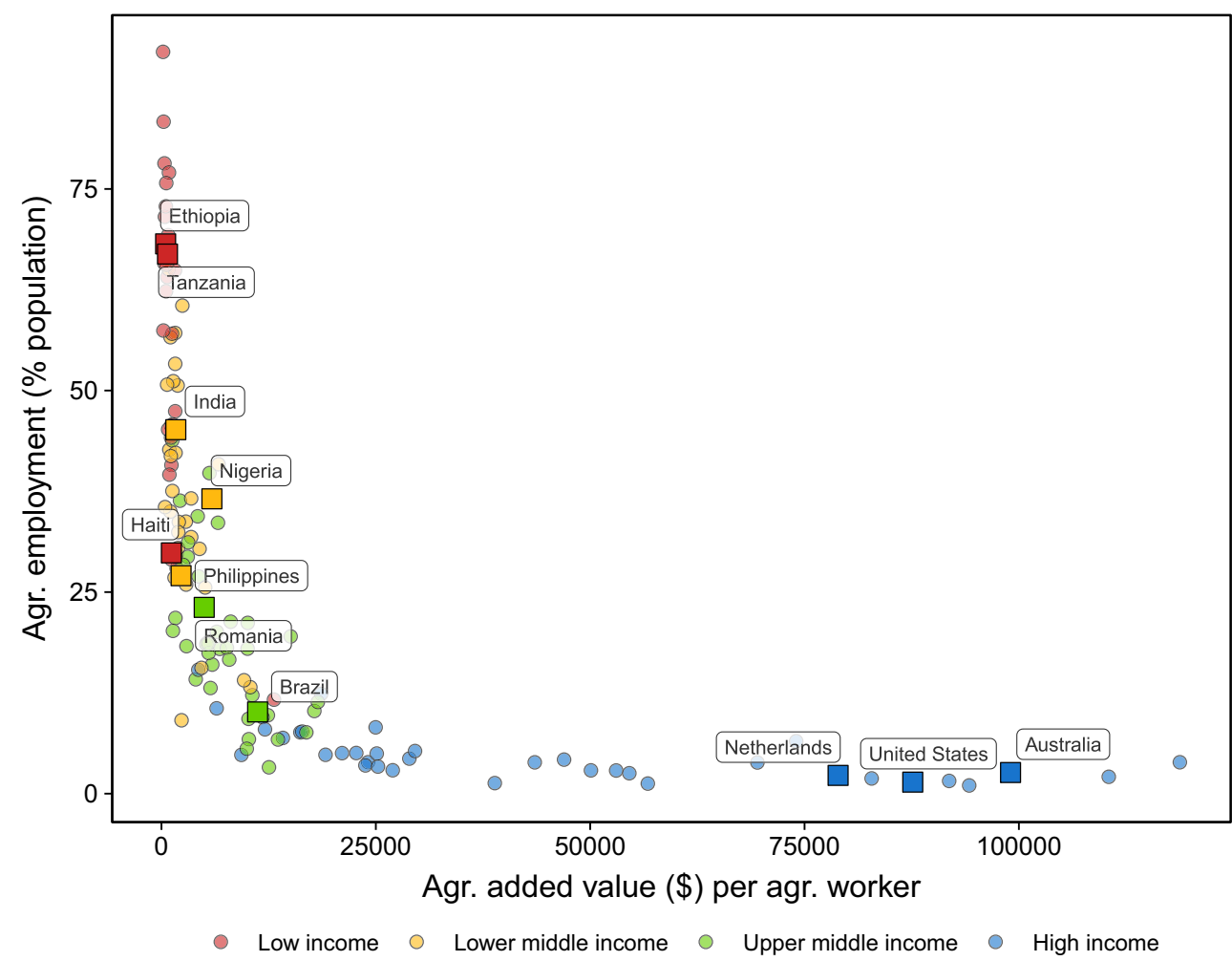

gaps are so large. The Asian Green Revolution and incidental productivity booms in smallholder agriculture in Africa - i.e. Zimbabwe's agricultural revolution in the 1980s (Rukuni \& Eicher, 1994) - testify to the large impacts relatively localized productivity growth can have.

\subsection{Countries that depend most on agriculture for income earn the least}

When we examine the dependence of different countries on agriculture (expressed as \% GDP), a familiar pattern emerges. In line with the generalized model of structural transformation (Timmer, 2009), countries most dependent on agriculture as a source of employment derive the largest share of their GDP from agriculture (Fig. 6). Most food exporting regions are also high-income countries (Clapp, 2017) which derive only a small proportion of their GDP from agriculture, and where only a small fraction of the population is involved in agricultural work (Fig. 6). This results in a strong inverse relationship between agricultural employment and labour productivity expressed as the economic value added per worker. Of course, the dependence on agriculture reflects the weak development of, and opportunities for employment in, other economic sectors. Agricultural development has often been a main driver of economic structural transformation. But the question remains as to whether agriculture can drive economic development and reduce poverty when employment opportunities outside agriculture remain very limited, as in many countries of subSaharan Africa. A lack of productivity growth in nonagricultural sectors appears to act as a lid on the agricultural engine of growth.

In many parts of the world, agricultural mechanisation and increased technology use leads to large increases in productivity per agricultural worker and goes hand-inhand with increases in farm size. This can even be observed at the level of simple technology, where ox-drawn ploughs allow larger areas to be cultivated and increase labour productivity as compared with hand hoes. Yet, despite mechanisation, rates of land consolidation in Southeast Asian countries are generally very low (see section 3.4, Liu et al., 2020). Meanwhile, use of yield-improving technologies on-farm leads to an overall decrease in the number of agricultural jobs, as the agricultural service sector cannot absorb the labour that farms shed.

\subsection{Population density or alternative jobs? What drives agricultural transformation in developing countries?}

Historical trends suggest that a certain population density is necessary for intensification to occur; in African countries yields have increased only where population densities exceed 2.5 people per ha (Breman et al., 2019) - one often cited 
explanation for the lack of a Green Revolution in sub-Saharan Africa (Djurfeldt et al., 2005).

On the other hand, alternative employment opportunities are needed before the consolidation of small farms into larger, potentially more economically viable units can occur. But whereas rural populations in Asia are beginning to plateau or decline (as they did in Europe), in sub-Saharan Africa they will continue to increase strongly for the foreseeable future, despite rapid urbanisation (United Nations, 2018). And although the proportion of workers in agriculture continues to fall, their absolute number is still increasing (Christiaensen \& Brooks, 2018); an indication that the prospects for farm consolidation in sub-Saharan Africa are small. Employment growth outside agriculture is simply not large enough. Consequently, in most countries in SSA, there are few alternatives for young people than to remain in agriculture (ACET, 2014; Christiaensen, 2020; Sumberg, 2021). Thus, farming remains the single largest occupation of rural youth, and there is no general trend of depopulation in rural Africa, somewhat similar to the situation in India. Essentially this remains an economic lock-in.

The lack of alternative jobs implies that raising agricultural productivity and diversification to produce higher-value crops are critically important to increase farmers' income, particularly as there is no other apparent engine for rural economic growth. The economic lock-in is also evident in the lack of investment in technological change in agriculture. Yet, in the predominantly rainfed agricultural systems of Africa, farm sizes are often already so small that (sustained) investments in technological change are unlikely to be profitable, and small farms are unlikely to generate the investment capital required for technological change. For example, direct investment in mechanisation is only profitable for farms of a certain size per farm worker, although smallholders may access mechanisation through service providers. Farmer organisations (e.g. saving and lending clubs, cooperatives or unions) also offer opportunities to access inputs, technology and markets.

However, what is mostly needed, is jobs - alternative employment. This can draw people out of agriculture, and enable some degree of farm consolidation. Frankema and van Waijenburg (2018) suggest that domestic market integration could become the engine for growth; intensification and diversification of rural-urban exchange networks, which may lead to better market functioning and economies of scale in commodity production and services. Over what time scale such developments might happen, is unclear.

\subsection{The fluidity of farming: Beyond existing categorisations}

Not least due to the tight margins on produce, farming households diversify incomes everywhere. The persistent strain on the economic viability of farming has led to off-farm income generation in rural households. This is not merely a problem for smallholder farms in Asia or Africa, but also for substantially larger and more capitalised farm enterprises in both developed and less-developed countries (Weltin et al., 2017). Examples are windmills for electricity generation, agritourism, farmers managing nature areas, and so called, care farms for people with disabilities. Such diversification calls the validity of existing categorisations into question - e.g. is the farm still a meaningful economic unit?

Although we tend to have an image in our minds of a farm as a fairly fixed, physical unit of land, there is an increasing number of exceptions that do not fit this image. The interchange of land through hiring or sharecropping is a common practice in all corners of the world (e.g. Adjei-Nsiah et al., 2004). Such practices are increasingly common, especially where farm size becomes a constraint. For instance, in China, many ultra-small farms are managed as larger units to allow mechanisation; in 2017, 36.5\% of all land usage rights were rented out to other farmers, cooperatives or firms, following recent legislative changes (Hayes et al., 2018). In densely-populated parts of western Kenya, we see individuals renting land from several neighbours to create a more economically-viable scale of production. Such trends often remain obscured in agricultural statistics that focus on farm ownership.

In northern Europe, highly specialised farmers utilise the latest technology for the production of specific crops; they can afford to rent land, profiting from technology-enabled economies of scale, while remaining flexible. The large investment costs of specialised equipment that is used within a short time window of the growing season precludes ownership by individual farmers. Thus, many farm operations are conducted by companies contracted to provide services, where the farmer is a specialist who manages his/her farm.

Similar problems of categorization are apparent for agricultural labour and labour productivity. For instance, low agricultural labour productivity in sub-Saharan Africa is, at least partly, an artefact. (McCullough, 2017). First, people work fewer hours in a year in agriculture than those employed in other sectors. This points to 'hidden unemployment' suggesting that a large reserve of labour exists in rural Africa. Second, there are issues as to who is categorised as an agricultural labourer. In surveys, people are generally registered on the basis of their primary income source, whilst they often engage in more activities, particularly in slack periods when farming demands less attention. Thus people are classified as employed full-time in agriculture whereas in reality they devote only part of their time to farming activities (World Bank, 2020b; Frelat et al., 2016). On the other hand, others who are not classified as agricultural workers, help out during peak periods, including children, are often not accounted for in agricultural statistics. Hence, the clear categorization of 
labourers into distinct economic sectors, which may seem to be logical and illuminating for structurally-transformed economies, actually obscures trends in sub-Saharan Africa.

\section{Who are the farmers of the future?}

In this section we return to the question of who will produce our food in the future. As highlighted in the introduction, the debate on the future of farming often focuses on the principles of production - i.e. whether agricultural production should be agro-ecological, organic, regenerative or 'conventional' rather than on the relations between different elements of the global food system, or the interdependencies between different types of agricultural systems. However, calls for the reform of 'conventional' agriculture toward more ecologicallyfriendly ways of food production provide little concrete guidance for agricultural development in particular regions of the world. Not only is 'conventional agriculture' highly diverse, so is its environmental footprint. The trends and transformations required in large-scale, capital-intensive agriculture cannot serve as a policy model for smallholder agriculture in the Global South, which is less capitalised and has a much smaller environmental footprint. Yet, such trends and transformations are highly relevant for the Global South as they impact global markets, and thereby the context within which agriculture will develop.

At the same time the profitability of farming is a huge concern globally. To transform the diverse farms and farming systems across the world, while ensuring their viability, requires strong policy frameworks that can stimulate both higher productivity, more environmentally friendly production methods and allow for the co-existence of diverse farms and farming systems. But what do such possible transformations in agriculture look like in different parts of the world?

\subsection{Trends in large-scale farming: Specialisation, di- versification and integration at different scales}

Farmers operate in complex socio-economic conditions and compete in local and global markets. Although individual farmers struggle to maintain viability on nearly all continents, net food exporting countries still have potential to increase their production. Plant breeding (perhaps with wider acceptance of genetic modification in future) and improved management continue to shift production potential upwards, and productivity is still rising (albeit with some signs of levelling off - Cassman \& Grassini, 2020). Technological developments in large-scale farming systems within well organised value-chains drive a process of lowering nominal prices of agricultural commodities (Koning et al., 2008). This will continue to drive many farmers to reduce operational costs and increase production to maintain their incomes. However, aggravating environmental problems, animal welfare concerns, human health issues, and stronger voices of consumers will steer agricultural production towards lower environmental footprint technologies and value-adding marketing channels. Although affordable food prices will remain important, it seems unavoidable that environmental costs (and perhaps the progressively recognised social and human health costs) incurred by the production and consumption of food will be internalised in agricultural systems. This is likely to lead to lower output/input price ratios, and drive capital-intensive farms which already operate near the local production potential to become more efficient with (on-farm) available resources, while using less external inputs (per hectare and per unit of produce). In turn, this will help to sustain the environment, and to cope with finite resources while avoiding further biodiversity loss. Urban farming is also likely to grow in significance, as are alternative forms of protein production. These changes can have far-reaching effects on the environment, on international trade in all kinds of commodities, but also on individual farmers. These changes will take place in the main food source areas of the world and will have consequences on food sinks - on the food supply of food-importing countries. Such changes will therefore require international coordination and agreement, which is far from trivial. But it is hard to imagine that the road of cost minimisation without accounting for all sorts of externalities can be maintained.

Whether this means that the world will develop towards a system with a larger focus on regionally produced food with a reduced dependency on international trade is not (yet) evident. Clearly, some geographies are far more suitable than others for the production of specific commodities and selfsufficiency for all regions is neither feasible nor efficient (Clapp, 2017). However, more regionalised production certainly has advantages with respect to transport costs and associated emissions, and is more supportive of diverse farming systems and farming livelihoods. More regionalised production systems may enable niche market producers to co-exist with large-scale, low-cost farms and protect smallholder producers in the Global South from the vagaries of globalized markets. Such trends require a concomitant shift in policies, away from a focus on global free trade in agricultural produce, towards policies that support and shield regionalised production and smallholder producers.

In the increased use of available resources and lower dependency on external inputs, the recoupling of cropping and livestock is an important means of making large-scale intensive agriculture more circular (de Boer \& van Ittersum, 2018). Whether such re-coupling takes shape at the farm, at the farming system, or at the regional level is a moot point (Schut et al., 2020), but mixed farming systems seem best suited to risky environments (Garrett et al., 2020). 
Another important aspect of future farming systems is the embedding of ecosystems services including biodiversity conservation within landscapes. Such landscapes may take the form of highly productive, intensive farms combined with wildflower strips (Grass et al., 2016) and nature reserves (land-sparing), to less intensive farms and farming systems with more on-farm biodiversity (Seufert \& Ramankutty, 2017) (land-sharing). We expect diverse landscapes, with a mix of intensive and extensive forms of agriculture combined with nature reserves are likely to develop (Ekroos et al., 2016). Further, future climates with more extreme conditions require attention for fresh water storage in lakes and ground-water to reduce impacts of droughts, but also buffering capacity to reduce impacts of floods. Strong policy frameworks, supporting both intensive and more extensively operating farms of different sizes, are required to sustain such biodiverse landscapes.

A combination of narrow economic margins and technology development is driving the emergence of corporate forms of production. The development of productivity-enhancing technology for very specific farming operations, such as minimum tillage, weed control, etc. reduces costs and enables better management, but requires operation at scale to be profitable. Corporate farms are well placed to take advantage of these developments. Companies can also spread their investments across different types of farms and in different agro-ecological zones to buffer against price and climate risks. Management board-type structures that incorporate finance, human resource management, legal skills, marketing and agronomic skills are becoming more prevalent (Australian Farm Institute, 2015). Although not yet as common as in Australia, corporate farms are also emerging elsewhere, such as in Southeast Asia (section 3.4) and Europe, where one company manages 90,000 ha across five countries (see https:// www.spearheadinternational.com). Another company manages many types of farms in nine countries distributed across four continents (see https:// inglebyfarms.com/). Family farms also continue to develop along the path of scale enlargement. Alongside trends of increased investments in largescale highly mechanised agriculture, we are likely to witness further decline in rural employment and the depopulation of rural areas, in European countries, the Americas and Australasia. This leads to a spiral of disinvestment in services such as shops, schools, hospitals and other rural infrastructure, and to further migration to urban centres. Such trends are particularly prominent in less-favourable climates and more remote areas, contributing to the decline in the number of farms and farmers, and in the overall area under production in Europe.

\subsection{The future of smallholder farming}

Our main focus is on understanding the future of smallholder farming in sub-Saharan Africa, despite the fact that in absolute terms the number of smallholder farmers in Asia is much larger than in Africa. This is because the predicament smallholder farmers in Africa find themselves in is of a different nature than that of their Asian counterparts. Agricultural development in Asia has been strongly guided by - smallholderoriented - agricultural policies (Henley, 2012) and has taken place in the context of an industrialisation of local economies offering alternative employment opportunities. Furthermore, overall populations in Asia, and in particular rural populations, are stabilising or start to decline. In stark contrast, rural populations in Africa are still doubling every 20 years, against a backdrop of farm sizes which are already small. What does this mean for the future of African farming systems? As discussed in section 6, it is hard to see that food production can keep pace with growing demand without expansion of the cropped area, no matter how undesirable for biodiversity conservation and other ecosystem services. Yet, so-called un(der)utilized land is often in remote areas, far from markets (Chamberlin et al., 2014) and increasingly in agriculturally marginal areas, which increases the vulnerability of agricultural production to climate variability (Andersson, 2007).

Our analysis of the future of smallholder farming in Africa portrays a bleak picture, as alternative strategies to deal with current constraints hold relatively little promise in the short term. For instance, Headey and Jayne (2014) make the point that diversifying employment through non-farm activities, domestic and international migration, although important, will not be able to absorb sufficient numbers of farmers stepping out of agriculture. Unlike most of Asia, most of Africa is not characterised by a rapidly expanding urban manufacturing sector that can absorb rural-urban migrants. Relative high wages in comparison to Asia are probably an important factor in this sluggish industrial development, partly because food prices are relatively high (Breman et al., 2019). In Africa, 'consumption cities' predominate over 'production cities'. At the heart of the problem lies what has been termed the 'Food Security Conundrum' (Giller, 2020a) which is the nexus of three factors. First, African countries need an abundant supply of affordable and nutritious food for their burgeoning rural and urban populations. Second, agriculture is a major contributor to the balance of payments for African economies, meaning that much of the focus of governments is on produce for export rather than food security. Third, as we have seen from our analysis, most rural households lack sufficient land, labour or economic incentives to invest in food production. A significant proportion of smallholders does not benefit from productivity increasing technologies, and just 'hang-in' (Thornton et al., 2018; Dorward, 2009) in absence of economic alternatives. 
To make farming more profitable and attractive, substantial improvements in the enabling conditions are needed. The list of potential interventions is long and well-established. Reducing transport costs by investment in infrastructure, more effective extension services based on tailored agronomic research, an enhanced role of the private sector to name a few. Input subsidy programmes implemented in many countries of sub-Saharan Africa over the past 10 years have increased the use of fertilizer, but with insufficient attention to ensuring they are used efficiently (Jayne et al., 2018). Other good agronomic practices, including improved cultivars and seed, plant density and weed, pest and disease management are needed for this. Crop insurance and other policies to buffer smallholders against climate and market risks are essential, particularly in the face of increased climate variability resulting from climate change.

Yet, without a fundamental transformation of African agriculture that allows for the consolidation of small farms into larger and more economically-viable units, it is unlikely that substantial intensification of farming will occur. Given a lack of livelihood security outside agriculture and the significant non-productive meanings of land in many African cultures, for example as the rural home, a place of belonging, where ancestors are buried (Andersson, 2002), the consolidation of land through purchase seems unlikely, at least in the short term. Land rental or share-cropping appear much more likely options which can provide the economies of scale to allow investment in inputs and mechanisation to enhance both labour and land productivity. No doubt production of commodities such as cocoa, coffee, cotton and tea will continue to be important agricultural exports as well as important income streams for smallholders and the national economies. Boosting production for national markets could also contribute strongly to national economies by reducing the need for imports. A good example is soybean; there is increasing demand throughout SSA for soy cake as feed for poultry and aquaculture which is largely met by import of processed cake from South America. The use of temporary tariffs to stabilise prices, or price guarantees for farmers to de-risk their investment are means to expand the fledgling local feed industries until the production volumes increase to become competitive with imports. The moves to create free trade zones within the African continent could also enhance production for national and regional markets.

History has taught us that agricultural development is conditional for economic development - but how can the conditions be created to foster development of the agricultural sector? Perhaps the greatest challenge lies in creating the employment needed outside agriculture to provide alternatives to farming (Christiaensen, 2020). One promising trend is the development of smaller urban centres in otherwise rural areas (United Nations, 2018). This may create incentives for more local market-oriented production and opportunities for value addition in processing resulting in a virtuous cycle of farm and non-farm activities supporting each other (Agergaard et al., 2018). The improvement in infrastructure associated with urban development may foster these developments. Analysis of past developments in Asia shows that a multi-layered and diverse range of pro-poor policies and investments are needed to stimulate rural development, including agriculture (Henley, 2015).

A crucial question that remains concerns the provision of social safety nets for rural households who lack resources to make a living income from farming and lack alternative employment. Banerjee and Duflo (2019) argue for an ultrabasic, universal basic income for all. Such an approach of direct cash payments to farmers is already being tried in India, as an alternative to direct provision of food support. Such an universal basic income would also provide a buffer against the risk of crop failure - and help to prepare smallholders for impacts of climate change. Investment in health and education for all, and especially for girls, will be critical to slow rates of population growth in Africa and equip the future labour force (United Nations, 2019).

Farming will remain an important component of rural livelihoods but cannot deliver economic growth as currently assumed by many policy initiatives in Africa. Currently, all problems of rural development appear to be placed on farming - whereas agriculture should be seen as one component of rural life, albeit a central component of rural livelihoods. Agronomic research continues to focus on technologies for yield improvement, but against a backdrop of farm structures and farmer livelihoods which prevent farmers to 'step-up' their operations. Yield-improving technologies remain nevertheless crucial for their contribution to rural households' food and nutrition security. A broader dialogue is needed on how to transform and harness the potential of smallholder agriculture, whilst addressing other opportunities for employment in rural and urban areas and - at the very least - avoiding further environmental degradation and limiting expansion of the land area under agriculture.

\subsection{Concluding remarks}

Approaching the question of 'Who will produce our food?' requires a food systems approach at global level, given how interconnected the world is in terms of agricultural trade and the role of agriculture and food in our economies. Our analysis has revealed a bewildering diversity, with farms ranging in size from less than 0.1 ha to more than 10,000 ha. Yet the prices paid for farm produce, apart from niche products, are largely determined by global markets, and these prices are showing a downward trend in real terms. Smallholder farms will continue to produce the major share of the food in rural areas and will be critical to the food security of a large proportion of the world's population. Investment in smallholder agriculture, and the broader infrastructure and institutions to 
support it, remains the most direct way to address food security and rural poverty. But without a fundamental revision of policies and pricing, it is hard to imagine at global scale any other pathway than a further marginalization of smallholder farmers, and an increasing dependence on large-scale farming.

Depending on one's personal perspective, we might consider neither the smallest nor the largest farms as desirable or sustainable. Wealthy consumers and planetary boundaries push for food to be grown with less inputs, to be grown more locally, and this can create opportunities for farmers to supply these local markets and sell - organic, regionally-produced, or certified - produce at higher prices. There is little market for such higher priced products in developing countries, yet global debates often operate on a level that conflates all food production into one basket, which our analysis demonstrates is meaningless. In addition, consumer concern about issues such as equity, health, environmental impacts and biodiversity results in additional costs that cannot be placed in the lap of the farmer. Approaches for investment in agriculture should be selected by the countries and smallholder farmers themselves to ensure that the local opportunities and constraints are addressed (Giller, 2020b).

There is no doubt that agriculture will remain a central pillar of rural livelihoods in developing countries in future. Opportunities exist to diversify farming to produce more nutritious diets, to broaden from dependence on staple cereals to include a wider range of root and tuber crops such as cassava, potato and highland banana - and more nutritious crops such as pulses and vegetables. But the meagre incomes that farmers can generate from farming alone evidences that they are part of a broader food system; they also need other forms of income to purchase the nutritious foods that they cannot produce themselves.

Aggravating environmental problems, climate change, animal welfare concerns, human health issues, and stronger voices of retailers and consumers will steer agricultural policies and production towards lower environmental footprint technologies and marketing channels. Although affordable food prices will remain important, it seems unavoidable that environmental costs (and perhaps social and human health costs) incurred by the production and consumption of food will need to be internalised in the long-term. Ultimately this should lead to farming that produces, next to food, a range of ecosystem services at prices which sustain a living income for producers of food and respect the planetary boundaries. It seems beyond doubt this can only be achieved within a strongly reformed economic context. The latter is controversial, but perhaps it is time to ensure that the economy should serve the planet and the people, rather than accepting the contrary.

Acknowledgments We are grateful to the International Fund for Agricultural Development (IFAD) for funding much of the data analysis as part of the Towards Inclusive, Sustainable, Nutritious and Efficient
Food Systems project. We thank Leslie Lipper and Serge Savary for their insightful reviews and Bart de Steenhuijsen Piters for his comments on an earlier draft. KEG and MKvI thank the NWO-WOTRO Strategic Partnership NL-CGIAR for funding. JAA acknowledges funding from the CRP on Maize through CIMMYT's 'Rural livelihood-oriented research methodologies for social impact analyses of Sustainable Intensification interventions' project. AK acknowledges support from ACIAR through the Sustainable Development Investment Portfolio (SDIP) programme. MKvI and JVS thank the Bill \& Melinda Gates Foundation for funding the establishment of the Global Yield Gap Atlas. JH acknowledges funding from USAID Feed the FutureAfricaRISING Ethiopia and $\mathrm{JH}$ and MvW the CGIAR Research Program on Livestock.

\section{Declarations}

Conflict of interest The authors declare that they have no conflict of interest.

Open Access This article is licensed under a Creative Commons Attribution 4.0 International License, which permits use, sharing, adaptation, distribution and reproduction in any medium or format, as long as you give appropriate credit to the original author(s) and the source, provide a link to the Creative Commons licence, and indicate if changes were made. The images or other third party material in this article are included in the article's Creative Commons licence, unless indicated otherwise in a credit line to the material. If material is not included in the article's Creative Commons licence and your intended use is not permitted by statutory regulation or exceeds the permitted use, you will need to obtain permission directly from the copyright holder. To view a copy of this licence, visit http://creativecommons.org/licenses/by/4.0/.

\section{References}

ABARES (2016). Wheat-sheep zone. Agricultural and grazing industries survey. Australian Bureau of Agricultural and Resource Economics.

ABARES - BRS (2010). Land use of Australia, version 4, 2005-06. Australian Bureau of Agricultural and Resource Economics Bureau of Rural Sciences.

Abate, T., Shiferaw, B., Menkir, A., Wegary, D., Kebede, Y., Tesfaye, K., Kassie, M., Bogale, G., Tadesse, B., \& Keno, T. (2015). Factors that transformed maize productivity in Ethiopia. [OriginalPaper]. Food Security, 7(5), 965-981. https://doi.org/10.1007/s12571-0150488-z.

Abson, D. J. (2019). Chapter 19-the economic drivers and consequences of agricultural specialization. In G. Lemaire, P. C. D. F. Carvalho, S. Kronberg, \& S. Recous (Eds.), Agroecosystem diversity (pp. 301315). Academic Press.

ACET (2014). African transformation report - growth with depth. http:// africantransformation.org/wp-content/uploads/2014/02/2014african-transformation-report.pdf. African Center for Economic Transformation.

Adiele, J. G. (2020). Growing out of hunger: Towards an improved understanding of the water and nutrient limited yield of cassava. Wageningen University.

Adiele, J. G., Schut, A. G. T., van den Beuken, R. P. M., Ezui, K. S., Pypers, P., Ano, A. O., Egesi, C. N., \& Giller, K. E. (2020). Towards closing cassava yield gap in West Africa: Agronomic efficiency and storage root yield responses to NPK fertilizers. Field Crops Research, 253, 107820 107811. https://doi.org/10.1016/j.fcr.2020.107820. 
Adjei-Nsiah, S., Leeuwis, C., Giller, K. E., Sakyi-Dawson, O., Cobbina, J., Kuyper, T. W., Abekoe, M., \& van der Werf, W. (2004). Land tenure and differential soil fertility management practices among native and migrant farmers in Wenchi, Ghana: Implications for interdisciplinary action research. NJAS Wageningen Journal of Life Sciences, 52, 331-348.

Agergaard, J., Tacoli, C., Steel, G., \& Ørtenblad, S. B. (2018). Revisiting rural-urban transformations and small town development in subSaharan Africa. The European Journal of Development Research, 31(1), 2-11. https://doi.org/10.1057/s41287-018-0182-z.

Alexander, P., Brown, C., Arneth, A., Dias, C., Finnigan, J., Doran, D., \& Rounsevell, M. D. A. (2017). Could consumption of insects, cultured meat or imitation meat reduce global agricultural land use? Global Food Security 15, 22-32.

Alexandratos, N., \& Bruinsma, J. (2012). World agriculture towards 2030/2050: The 2012 revision. ESA working paper no. 12-03. FAO.

Andersson, J. A. (2002). Sorcery in the era of 'Henry IV': Kinship, mobility and mortality in Buhera district, Zimbabwe. Journal of the Royal Anthropological Institute, 8(3), 425-449.

Andersson, J. A. (2007). How much did property rights matter? Understanding food insecurity in Zimbabwe: A critique of Richardson. African Affairs, 106(425), 681-690.

Australian Farm Institute (2015). The family farm is becoming less family. Ag Forum. http://www.farminstitute.org.au/_blog/Ag_Forum/post/ the-family-farm-is-becoming-less-family/.

Banerjee, A. V., \& Duflo, E. (2019). Good economics for hard times: Better answers to our biggest problems. Allen Lane.

Barona, E., Ramankutty, N., Hyman, G., \& Coomes, O. T. (2010). The role of pasture and soybean in deforestation of the Brazilian Amazon. Environmental Research Letters, 5, 024002. https://doi. org/10.1088/1748-9326/5/2/024002.

Baudron, F., Andersson, J. A., Corbeels, M., \& Giller, K. E. (2012). Failing to yield? Ploughs, conservation agriculture and the problem of agricultural intensification: An example from the Zambezi Valley, Zimbabwe. Journal of Development Studies, 48(3), 393412. https://doi.org/10.1080/00220388.2011.587509.

Benin, S. (2016). Conclusions and implications for raising and sustaining high agricultural productivity in Africa. In S. Benin (Ed.), Agricultural productivity in Africa: Trends, patterns, and determinants (pp. 335-347). International Food Policy Research Institute.

Bingen, R. J. (1998). Cotton, democracy and development in Mali. The Journal of Modern African Studies, 36(2), 265-285. https://doi.org/ 10.1017/S0022278X98002742.

Binswanger-Mkhize, H. P., \& Savastano, S. (2017). Agricultural intensification: The status in six African countries. Food Policy, 67, 26-40. https://doi.org/10.1016/j.foodpol.2016.09.021.

Boserup, E. (1965). The conditions of agricultural growth. Aldine.

Breman, H., Schut, A. G. T., \& Seligman, N. G. (2019). From fed by the world to food security. Accelerating agricultural development in Africa. Plant, Production Systems, Wageningen University. https:// doi.org/10.18174/498300.

Brian, J. P. (2004). Slave emancipation, trans-local social processes and the spread of Islam in French colonial Buguni (Southern Mali), 1893-1914. The Journal of African History, 45(3), 421-444.

Brody, C., De Hoop, T., Vojtkova, M., Warnock, R., Dunbar, M., Murthy, P., et al. (2015). Economic self-help group programs for improving women's empowerment: A systematic review. Campbell Systematic Reviews, 11(1), 1-182.

Cassman, K. G., \& Grassini, P. (2020). A global perspective on sustainable intensification research. Nature Sustainability, 3(4), 1-7. https://doi.org/10.1038/s41893-020-0507-8.
Cattelan, A. J., \& Dall'Agnol, A. (2018). The rapid soybean growth in Brazil. OCL - Oilseeds and Fats, Crops and Lipids, 25, D102. https://doi.org/10.1051/ocl/2017058.

Chakravorty, S. (2013). The price of land: Acquisition, conflict, consequence. Oxford University Press.

Chamberlin, J., Jayne, T. S., \& Headey, D. (2014). Scarcity amidst abundance? Reassessing the potential for cropland expansion in Africa. Food Policy, 48(C), 51-65. https://doi.org/10.1016/j.foodpol.2014. 05.002 .

Christiaensen, L. (2020). Agriculture, jobs, and value chains in Africa. Job Notes Issue No 9. https://openknowledge.worldbank.org/handle/10986/33693. Washington DC.

Christiaensen, L., \& Brooks, K. (2018). In Africa, more not fewer people will work in agriculture. https://blogs.worldbank.org/jobs/africamore-not-fewer-people-will-work-agriculture.

Clapp, J. (2017). Food self-sufficiency: Making sense of it, and when it makes sense. Food Policy, 66, 88-96. https://doi.org/10.1016/j. foodpol.2016.12.001.

Cleaver, K. M., \& Schreiber, G. A. (1994). Reversing the spiral: The population, agriculture and environment nexus in Sub-Saharan Africa. World Bank

Crowley, E. L., \& Carter, S. E. (2000). Agrarian change and the changing relationships between toil and soil in Maragoli, western Kenya (1900-1994). Human Ecology, 28, 383-414.

de Arruda, M. R., Slingerland, M., Santos, J. Z. L., \& Giller, K. E. (2019). Agricultural land use change and associated driving forces over the past 180 years in two municipalities of the Brazilian Cerrado. Geojournal, 84(3), 555-570. https://doi.org/10.1007/s10708-0189875-2.

de Boer, I. J. M., \& van Ittersum, M. K. (2018). Circularity in agricultural production. Wageningen University and Research. pp. 1-74. https:// www.wur.nl/en/show/Circularity-in-agricultural-production.htm

de Ridder, N., Breman, H., van Keulen, H., \& Stomph, T. J. (2004). Revisiting a 'cure against land hunger': Soil fertility management and farming system dynamics in the West African Sahel. Agricultural Systems, 80, 109-131.

Dinar, A., Mendelsohn, R., Evenson, R., Parikh, J., Sanghi, A., Kumar, K., McKinsey J., Lonergan S. (1998). Measuring the impact of climate change on Indian agriculture. The World Bank.

Djurfeldt, G., Holmén, H., Jirström, M., \& Larsson, R. (2005). The African food crisis. Lessons from the Asian green revolution. CABI Publishing.

Dorward, A. (2009). Integrating contested aspirations, processes and policy: Development as hanging in, stepping up and stepping out. Development Policy Review, 27, 131-146.

Eastwood, R., Lipton, M., \& Newell, A. (2010). Farm size, chapter 65. In Handbook of agricultural economics (vol. 4, pp. 3323-3397, https:// doi.org/3310.1016/0305-3750X(3390)90047-90042.). Elsevier.

EC (2020). Communication from the commission to the European parliament, the council, the European economic and social committee and the committee of the regions. Directorate General for Agriculture and Rural Development, European Commission. $\operatorname{COM}(2020) 846$ final.

Ekroos, J., Ödman, A. M., Andersson, G. K. S., Birkhofer, K., Herbertsson, L., Klatt, B. K., Olsson, O., Olsson, P. A., Persson, A. S., Prentice, H. C., Rundlöf, M., \& Smith, H. G. (2016). Sparing land for biodiversity at multiple spatial scales. [Review]. Frontiers in Ecology and Evolution, 3(145). https://doi.org/10.3389/fevo. 2015.00145 doi:10.3389/fevo.2015.00145.

Eloy, L., Aubertin, C., Toni, F., Lúcio, S. L. B., \& Bosgiraud, M. (2016). On the margins of soy farms: Traditional populations and selective environmental policies in the Brazilian Cerrado. Journal of Peasant 
Studies, 43, 494-516. https://doi.org/10.1080/03066150.2015. 1013099.

Escobar, N., Tizado, E. J., Zu Ermgassen, E. K. H. J. H. J., Löfgren, P., Börner, J., \& Godar, J. (2020). Spatially-explicit footprints of agricultural commodities: Mapping carbon emissions embodied in Brazil's soy exports. Global Environmental Change, 62, 102067. https://doi.org/10.1016/j.gloenvcha.2020.102067.

EUROSTAT (2020). Organic operators by status of the registration process (from 2012 onwards). https://ec.europa.eu/eurostat/ databrowser/view/org_coptyp/default/table?lang=en. European Statistical Office.

Falconnier, G. N., Descheemaeker, K., Van Mourik, T. A., Sanogo, O. M., \& Giller, K. E. (2015). Understanding farm trajectories and development pathways: Two decades of change in southern Mali. Agricultural Systems, 139, 210-222. https://doi.org/10.1016/j.agsy. 2015.07.005.

FAO (2019a). Agrarian structure in Latin America, (pp. 1-22). FAO.

FAO (2019b). Main results and metadata by country (2006-2015), (pp. 1-22). World Programme for the Census of Agriculture 2010. Available from http:/www.fao.org/world-census-agriculture/ wcarounds/wca2010/en/ FAO Statistical Development Series.

FAO (2020). Production, trade, (FAOSTAT database collections). Rome. Available from http://www.fao.org/faostat/en/\#data: FAO.

Frankema, E., \& van Waijenburg, M. (2018). Africa rising? A historical perspective. African Affairs, 117(469), 543-568. https://doi.org/10. 1093/afraf/ady022.

Frelat, R., Lopez-Ridaura, S., Giller, K. E., Herrero, M., Douxchamps, S., Djurfeldt, A. A., Erenstein, O., Henderson, B., Kassie, M., Paul, B. K., Rigolot, C., Ritzema, R. S., Rodriguez, D., van Asten, P. J. A., \& van Wijk, M. T. (2016). Drivers of household food availability in sub-Saharan Africa based on big data from small farms. Proceedings of the National Academy of Sciences, USA, 113, 458463. https://doi.org/10.1073/pnas.1518384112.

Fuglie, K. (2018). Is agricultural productivity growth slowing? Global Food Security, 17, 73-83.

Gao, L., Huang, J., \& Rozelle, S. (2012). Rental markets for cultivated land and agricultural investments in China. [Article]. Agricultural Economics (United Kingdom), 43(4), 391-403. https://doi.org/10. 1111/j.1574-0862.2012.00591.x.

Garrett, R. D., Ryschawy, J., Bell, L. W., Cortner, O., Ferreira, J., Garik, A. V. N., Gil, J. D. B., Klerkx, L., Moraine, M., Peterson, C. A., dos Reis, J. C., \& Valentim, J. F. (2020). Drivers of decoupling and recoupling of crop and livestock systems at farm and territorial scales. Ecology and Society, 25(1), art24-40. https://doi.org/10. 5751/ES-11412-250124.

Giller, K. E. (2020a). The food security conundrum. Global Food Security, 26, 100431. https://doi.org/10.1016/j.gfs.2020.100431.

Giller, K. E. (2020b). Grounding the helicopters. Geoderma, 373, 114302. https://doi.org/10.1016/j.geoderma.2020.114302.

Giller, K. E., Hijbeek, R., Andersson, J. A., \& Sumberg, J. (2021). Regenerative agriculture: An agronomic perspective. Outlook on Agriculture, 50(1), 13-25.

GoI (2014a). Key indicators of land and livestock holdings in India. National Sample Survey Organisation, Ministry of Statistics and Programme Implementation, Government of India. Report no. NSS KI (70/18.1)

GoI (2014b). Key indicators of situation of agricultural households in India. National Sample Survey Organisation, Ministry of Statistics and Programme Implementation, Government of India. Report no. NSS KI(70/33).

GoI (2016). State of Indian agriculture, 2015-16. Ministry of Agriculture and Farmers Welfare, Department of Agriculture, Cooperation \&
Farmers Welfare, Directorate of Economics and Statistics, Government of India.

GoI (2018). Economic survey 2017-18. Ministry of Finance, Government of India.

GoI (2020). Agricultural statistics at a glance, 2019. Ministry of Agriculture, Government of India.

Grass, I., Albrecht, J., Jauker, F., Diekötter, T., Warzecha, D., Wolters, V., \& Farwig, N. (2016). Much more than bees - wildflower plantings support highly diverse flower-visitor communities from complex to structurally simple agricultural landscapes. Agriculture, Ecosystems and Environment, 225, 45-53. https://doi.org/10.1016/ j.agee.2016.04.001.

Hayami, Y. (2007). An emerging agricultural problem in highperforming Asian economies. The World Bank.

Hayes, D., Li, M., \& Zhang, W. (2018). Can China's rural land policy reforms solve its farmland dilemma? CARD Agricultural Policy Review. Iowa State University. https://www.card.iastate.edu/ ag_policy_review/article/?a $=78$.

Hazell, P. (2013). Is small farm led development still a relevant strategy for Africa and Asia? http://www.fondation-farm.org/zoe/doc/farm pointdevue_201309_phazell_en.pdf

Hazell, P., Poulton, C., Wiggins, S., \& Dorward, A. (2010). The future of small farms: Trajectories and policy priorities. World Development, 38, 1349-1361. https://doi.org/10.1016/j.worlddev.2009.1306. 1012.

Headey, D. D., \& Jayne, T. S. (2014). Adaptation to land constraints: Is Africa different? Food Policy, 48(C), 18-33. https://doi.org/10. 1016/j.foodpol.2014.05.005.

Henley, D. (2012). The agrarian roots of industrial growth: Rural development in South-East Asia and sub-Saharan Africa. Development Policy Review, 30(1), s25-s47. https://doi.org/10.1111/j.1467-7679. 2012.00564.x.

Henley, D. (2015). Africa-Asia development divergence. A question of intent. ZED Books.

Herrero, M., Thornton, P. K., Power, B., Bogard, J. R., Remans, R., Fritz, S., Gerber, J. S., Nelson, G., See, L., Waha, K., Watson, R. A., West, P. C., Samberg, L. H., van de Steeg, J., Stephenson, E., van Wijk, M., \& Havlík, P. (2017). Farming and the geography of nutrient production for human use: A transdisciplinary analysis. The Lancet Planetary Health, 1(1), e33-e42. https://doi.org/10.1016/ S2542-5196(17)30007-4.

Hunter, M. C., Smith, R. G., Schipanski, M. E., Atwood, L. W., \& Mortensen, D. A. (2017). Agriculture in 2050: Recalibrating targets for sustainable intensification. Bioscience, 67(4), 386-391. https:// doi.org/10.1093/biosci/bix010.

IBGE (2019). Censo agropecuário 2017: resultados definitivos. Censo agropecuário, pp. 1-105.

IFAD (2019). An outlook on Asia's agricultural and rural transformation: Prospects and options for making it an inclusive and sustainable one. IFAD.

International Labour Organization (2020). Employment distribution by economic activity - ILO modelled estimates. (ILOSTAT database). Available from https://ilostat.ilo.org/data/.

Jackson, T., Zammit, K., \& Hatfield-Dodds, S. (2020). Snapshot of Australian agriculture 2020. Australian Bureau of Agricultural and Resource Economics. ABARES Insights Issue 1, 2020. https://www.agriculture.gov.au/abares/publications/insights/ snapshot-of-australian-agriculture-2020\#: :text=Australian\% 20 agriculture $\% 20$ accounts $\% 20$ for $\% 3$ A, $\%$ E2\% $80 \% 9319 \%$ 20(Figure\%201).

Jakimow, T., Tallapragada, C., \& Williams, L. (2013). A future orientation to agrarian livelihoods: A case study of rural Telangana. Economic and Political Weekly, 48(26/27), 129-138. 
Jayne, T. S., Mason, N. M., Burke, W. J., \& Ariga, J. (2018). Review: Taking stock of Africa's second-generation agricultural input subsidy programs. Food Policy, 75, 1-14. https://doi.org/10.1016/j. foodpol.2018.01.003.

Jodhka, S., \& Kumar, A. (2017). Non-farm economy in Madhubani, Bihar. Social dynamics and exclusionary rural transformations. Economic and Political Weekly, 52(25/26), 14-24.

Koning, N., \& Van Ittersum, M. K. (2009). Will the world have enough to eat? Current Opinion in Environmental Sustainability, 1(1), 77-82. https://doi.org/10.1016/j.cosust.2009.07.005.

Koning, N. B. J., Van Ittersum, M. K., Becx, G. A., Van Boekel, M., Brandenburg, W. A., Van den Broek, J. A., et al. (2008). Long-term global availability of food: Continued abundance or new scarcity? Njas-Wageningen Journal of Life Sciences, 55(3), 229-292.

Kumar, R., Agrawal, N. K., Vijayshankar, P. S., \& Vasavi, A. R. (2020). State of rural and agrarian India: Report 2020, rethinking productivity and populism through alternative approaches. Network of Rural and Agrarian Studies (NRAS).

Kuo, K.-F. (2014). One-stop service for young farmers in Taiwan. In: International seminar on the enhanced entry of young generation into farming, 21-23 October, Jeonju, Korea.

Laris, P., Foltz, J. D., \& Voorhees, B. (2015). Taking from cotton to grow maize: The shifting practices of small-holder farmers in the cotton belt of Mali. Agricultural Systems, 133(C), 1-13. https://doi.org/10. 1016/j.agsy.2014.10.010.

Lathuillière, M. J., Johnson, M. S., Galford, G. L., \& Couto, E. G. (2014). Environmental footprints show China and Europe's evolving resource appropriation for soybean production in Mato Grosso, Brazil. Environmental Research Letters, 9, 074001. https://doi.org/ 10.1088/1748-9326/9/7/074001.

Lele, U., \& Stone, S. W. (1989). Population pressure, the environment and agricultural intensification: Variations on the Boserup hypothesis. World Bank.

Liu, Y., Barrett, C. B., Pham, T., \& Violette, W. (2020). The intertemporal evolution of agriculture and labor over a rapid structural transformation: Lessons from Vietnam. Food Policy, 94, 101913-101914. https://doi.org/10.1016/j.foodpol.2020.101913.

Mall, R. K., Singh, R., Gupta, A., Srinivasan, G., \& Rathore, L. S. (2006). Impact of climate change on Indian agriculture: A review. Climatic Change, 78, 445-478.

Mani, M., \& Sushenjit Bandyopadhyay, S. C., Anil Markandya, and Thomas Mosier. (2018). South Asia's hotspots: The impact of temperature and precipitation changes on living standards. South Asia development matters. World Bank.

McCullough, E. B. (2017). Labor productivity and employment gaps in Sub-Saharan Africa. Food Policy, 67, 133-152. https://doi.org/10. 1016/j.foodpol.2016.09.013.

Medina, G., Almeida, C., Novaes, E., Godar, J., \& Pokorny, B. (2015). Development conditions for family farming: lessons from Brazil. World Development, 74, 386-396.

Mellisse, B. T., Descheemaeker, K., Giller, K. E., Abebe, T., \& van de Ven, G. W. J. (2018a). Are traditional home gardens in southern Ethiopia heading for extinction? Implications for productivity, plant species richness and food security. Agriculture, Ecosystems and Environment, 252, 1-13. https://doi.org/10.1016/j.agee.2017.09. 026.

Mellisse, B. T., van de Ven, G. W. J., Giller, K. E., \& Descheemaeker, K. (2018b). Home garden system dynamics in Southern Ethiopia. Agroforestry Systems, 92(6), 1579-1595. https://doi.org/10.1007/ s10457-017-0106-5.

Mukherji, A. (2020). Sustainable groundwater management in India needs a water-energy-food nexus approach. Applied Economic Perspectives and Policy. https://doi.org/10.1002/aepp.13123.
Muller, A., Schader, C., Scialabba, N. E.-H., Brüggemann, J., Isensee, A., Erb, K.-H., et al. (2017). Strategies for feeding the world more sustainably with organic agriculture. Nature Communications, 8 , 1290. https://doi.org/10.1038/s41467-017-01410-w.

Muyanga, M., \& Jayne, T. S. (2014). Effects of rising rural population density on smallholder agriculture in Kenya. Food Policy, 48(C), 98-113. https://doi.org/10.1016/j.foodpol.2014.03.001.

Nin-Pratt, A. (2016). Agricultural intensification and fertilizer use.. In S. Benin (Ed.), Agricultural productivity in Africa: Trends, patterns, and determinants (pp. 199-246). International Food Policy Research Institute.

Nyombi, K. (2010). Understanding growth of East Africa Highland Banana: Experiments and simulation. $\mathrm{PhD}$ thesis, Wageningen University.

Nyssen, J., Frank1, A., Haile, M., Hurni, H., Descheemaeker, K., Crummey, D., Ritler, A., Portner, B., Nievergelt, B., Moeyersons, J., Munro, N., Deckers, J., Billi, P., \& Poesen, J. (2014). Environmental conditions and human drivers for changes to north Ethiopian mountain landscapes over 145years. Science of the Total Environment, 485-486(C), 164-179. https://doi.org/10.1016/j. scitotenv.2014.03.052.

OECD (2018). Review of agricultural policies in India. (Vol. http://www. oecd.org/officialdocuments/publicdisplaydocumentpdf/?cote $=$ $\mathrm{TAD} / \mathrm{CA}(2018) 4 /$ FINAL \& docLanguage $=$ En [as viewed on 20th December 2020]. ): Trade and agriculture Directorate Committee for Agriculture, Organisation for Economic Co-operation and Development.

Oldenburg, P. (1990). Land consolidation as land reform, in India. World Development, 18, 183-195.

Ollenburger, M. H., Descheemaeker, K., Crane, T. A., Sanogo, O. M., \& Giller, K. E. (2016). Waking the sleeping Giant: Agricultural intensification, extensification or stagnation in Mali's Guinea Savannah. Agricultural Systems, 148, 58-70. https://doi.org/10.1016/j.agsy. 2016.07.003.

Oskam, A. J., Meester, G., \& Silvis, H. J. (Eds.). (2011). EU policy for agriculture, food and rural areas (2nd ed.). Wageningen Academic Publishers.

Otsuka, K. (2013). Food insecurity, income inequality, and the changing comparative advantage in world agriculture. Agricultural Economics, 44(s1), 7-18.

Otsuka, K., Liu, Y., \& Yamauchi, F. (2016). The future of small farms in Asia. Development Policy Review, 34(3), 441-461.

Oxfam (2016). Desterrados: Tierra, poder y desigualdad en América Latina. Oxfam International (Vol. November, pp. 1-102).

Pandey, V., Gupta, A., \& Gupta, S. (2019). Labor and welfare impacts of a large-scale livelihoods program: Quasi-experimental evidence from India. The World Bank.

Parodi, A., Leip, A., De Boer, I. J. M., Slegers, P. M., Ziegler, F., Temme, E. H. M., Herrero, M. Tuomisto, H., Valin, H., Van Middelaar, C. E., Van Loon, J. J. A., \& Van Zanten, H. H. E. (2018). The potential of future foods for sustainable and healthy diets. Nature Sustainability 1(12), 782-789.

Pingali, P. L., \& Xuan, V. (1992). Vietnam: Decollectivization and rice productivity growth. Economic Development and Cultural Change, 40(4), 697-718.

Rao, P. P., Birthal, P. S., \& Joshi, P. K. (2006). Diversification towards high value agriculture: Role of urbanisation and infrastructure. Economic and Political Weekly, 41, 2747-2753.

Rausch, L. L., Gibbs, H. K., Schelly, I., Brandão, A., Morton, D. C., Filho, A. C., et al. (2019). Soy expansion in Brazil's Cerrado. Conservation Letters, 12, e12671. https://doi.org/10.1111/conl. 12671. 
Reddy, D. N., \& Mishra, S. (Eds.). (2009). Agrarian crisis in India. Oxford University Press.

Rekow, L. (2019). Socio-ecological implications of soy in the Brazilian Cerrado. Challenges in Sustainability, 7, 7-29. https://doi.org/10. 12924/cis2019.07010007.

Ricciardi, V., Ramankutty, N., Mehrabi, Z., Jarvis, L., \& Chookolingo, B. (2018). How much of the world's food do smallholders produce? Global Food Security, 17, 64-72. https://doi.org/10.1016/j.gfs. 2018.05.002.

Rubio, N. R., Xiang, N., David, L., \& Kaplan, D. L. (2020). Plant-based and cell-based approaches to meat production. Nature Communications 11(1), 6276.

Rukuni, M., \& Eicher, C. (1994). Zimbabwe's Agricultural Revolution. University of Zimbabwe Publications.

Ruthenberg, H. (1980). Farming systems in the tropics (3rd ed.). Clarendon Press.

Samberg, L. H., Gerber, J. S., Ramankutty, N., Herrero, M., \& West, P. C. (2016). Subnational distribution of average farm size and smallholder contributions to global food production. Environmental Research Letters, 11(12), 1-11. https://doi.org/10.1088/1748-9326/11/12/ 124010 .

Sauer, S. (2018). Soy expansion into the agricultural frontiers of the Brazilian Amazon: The agribusiness economy and its social and environmental conflicts. Land Use Policy, 79, 326-338. https:// doi.org/10.1016/j.landusepol.2018.08.030.

Schneider, S. (2016). Family farming in Latin America and the Caribbean: Looking for new paths of rural development and food security, (pp. 1-46). Food and Agriculture Organization of the United Nations and the International Policy Centre for Inclusive Growth of the United Nations Development Programme.

Schut, A. G. T., Cooledge, E. C., Morainec, M., van de Ven, G. W. J., Jones, D. L., \& Chadwick, D. R. (2020). Re-integration of croplivestock systems in Europe: An overview. Frontiers of Agricultural Science and Engineering, 8, 111. https://doi.org/10. 15302/J-FASE-2020373.

Seo, J. S. (2014). Korea's small but strong farms' policy: International perspective for current and next generation. Paper presented at the FFTC-RDA international seminar on enhanced entry of young generation into farming, 21-23 October Jeonju, Korea,

Seufert, V., \& Ramankutty, N. (2017). Many shades of gray-the contextdependent performance of organic agriculture. [Review]. Science Advances, 3(3), e1602638. https://doi.org/10.1126/sciadv.1602638.

Shah, T., Giordano, M., \& Mukherji, A. (2012). Political economy of the energy-groundwater nexus in India: Exploring issues and assessing policy options. Hydrogeology Journal, 20, 995-1006.

Smithson, P. C., McIntyre, B. D., Gold, C. S., Ssali, H., Night, G., \& Okech, S. (2004). Potassium and magnesium fertilizers on banana in Uganda: Yields, weevil damage, foliar nutrient status and DRIS analysis. Nutrient Cycling in Agroecosystems, 69(1), 43-49.

Springmann, M., Clark, M., Mason-D’Croz, D., Wiebe, K., Bodirsky, B. L., Lassaletta, L., de Vries, W., Vermeulen, S. J., Herrero, M., Carlson, K. M., Jonell, M., Troell, M., DeClerck, F., Gordon, L. J., Zurayk, R., Scarborough, P., Rayner, M., Loken, B., Fanzo, J., Godfray, H. C. J., Tilman, D., Rockström, J., \& Willett, W. (2018). Options for keeping the food system within environmental limits. Nature, 562, 519-525 https://doi.org/510.1038/s41586-4101840594-41580. https://doi.org/10.1038/s41586-018-0594-0.

Sumberg, J. (Ed.). (2021). Youth and the rural economy in Africa: Hard work and Hazard. CABI.

Taulya, G. (2015). Ky'osimba onaanya: Understanding productivity of East African highland banana. Plant production systems. Wageningen University.
Tefft, J. (2010). Mali's white revolution: Smallholder cotton, 1960-2006. In S. Haggblade, \& P. B. R. Hazell (Eds.), Successes in African agriculture: Lessons for the future (pp. 113-162). International Food Policy Research Institute.

Thapa, G., \& Gaiha, R. (2011). Smallholder farming in Asia and the Pacific: Challenges and opportunities. In IFAD conference on new directions for smallholder agriculture, Rome, (vol. 25). International Fund for Agricultural Development.

Thornton, P. K., Kristjanson, P., Förch, W., Barahona, C., Cramer, L., \& Pradhan, S. (2018). Is agricultural adaptation to global change in lower-income countries on track to meet the future food production challenge? Global Environmental Change, 52, 37-48. https://doi. org/10.1016/j.gloenvcha.2018.06.003.

Tilman, D., Balzer, C., Hill, J., \& Befort, B. L. (2011). Global food demand and the sustainable intensification of agriculture. Proceedings of the National Academy of Sciences, USA, 108, 20260-20264

Timmer, C. P. (2009). A world without agriculture: The structural transformation in historical perspective. The AEI Press.

Tittonell, P., \& Giller, K. E. (2013). When yield gaps are poverty traps: The paradigm of ecological intensification in African smallholder agriculture. Field Crops Research, 143, 76-90. https://doi.org/10. 1016/j.fcr.2012.10.007.

Tittonell, P., van Wijk, M. T., Herrero, M., Rufino, M. C., de Ridder, N., \& Giller, K. E. (2009). Beyond resource constraints - exploring the biophysical feasibility of options for the intensification of smallholder crop-livestock systems in Vihiga district, Kenya. Agricultural Systems, 101(1-2), 1-19. https://doi.org/10.1016/j.agsy.2009.02. 003.

United Nations (2015). Resolution adopted by the General Assembly on 25 September 2015. 70/1 transforming our world: The 2030 agenda for sustainable development. United Nations General Assemby.

United Nations (2018). World Urbanisation Prospects: The 2018 Revision. Washington DC. Online Edition. United Nations, Department of Economic and Social Affairs, Population Division. Available from https://population.un.org/wup/Download/.

United Nations (2019). World population prospects: The 2019 revision. Department of Economic and Social Affairs, Population Division, United Nations. Online Edition. Rev. 1. Available from https:// population.un.org/wpp/Download/Standard/Population/.

van Dijk, M., Morley, T., van Loon, M., Reidsma, P., Tesfaye, K., \& van Ittersum, M. K. (2020). Reducing the maize yield gap in Ethiopia decomposition and policy simulation. Agricultural Systems, 183, 102828. https://doi.org/10.1016/j.agsy.2020.102828.

van Ittersum, M. K., Cassman, K. G., Grassini, P., Wolf, J., Tittonell, P., \& Hochman, Z. (2013). Yield gap analysis with local to global relevance - a review. Field Crops Research, 143, 4-17.

van Ittersum, M. K., van Bussel, L. G. J., Wolf, J., Grassini, P., van Wart, J., Guilpart, N., Claessens, L., de Groot, H., Wiebe, K., MasonD'Croz, D., Yang, H., Boogaard, H., van Oort, P. A. J., van Loon, M. P., Saito, K., Adimo, O., Adjei-Nsiah, S., Agali, A., Bala, A., Chikowo, R., Kaizzi, K., Kouressy, M., Makoi, J. H. J. R., Ouattara, K., Tesfaye, K., \& Cassman, K. G. (2016). Can sub-Saharan Africa feed itself? Proceedings of the National Academy of Sciences, 113(52), 14964-14969. https://doi.org/10.1073/pnas.1610359113.

Vasavi, A. R. (2012). Shadow space: Suicides and the predicament of rural India. Three Essays Collective.

Vijayabaskar, M., \& Menon, A. (2017). Peripheral agriculture? Macro and micro dynamics of land sales and land use changes in the 'rural' economy of Kancheepuram. In R. Nagaraj, \& S. Motiram (Eds.), Political economy of contemporary India (pp. 205-229). Cambridge University Press. 
Vijayabaskar, M., Narayanan, S., \& Srinivasan, S. (2018). Agricultural revival and reaping the youth dividend. The Economic and Political Weekly, 53(26-27), 8-16 https://www.epw.in/journal/2018/20262027.

van Vliet, J. A., Schut, A. G. T., Reidsma, P., Descheemaeker, K., Slingerland, M., van de Ven, G. W. J., \& Giller, K. E. (2015). Demystifying family farming: Features, diversity and trends across the globe. Global Food Security, 5(0), 11-18. https://doi.org/10.1016/j. gfs.2015.03.001.

Vollset, S. E., Goren, E., Yuan, C.-W., Cao, J., Smith, A. E., Hsiao, T., Bisignano, C., Azhar, G. S., Castro, E., Chalek, J., Dolgert, A. J., Frank, T., Fukutaki, K., Hay, S. I., Lozano, R., Mokdad, A. H., Nandakumar, V., Pierce, M., Pletcher, M., Robalik, T., Steuben, K. M., Wunrow, H. Y., Zlavog, B. S., \& Murray, C. J. L. (2020). Fertility, mortality, migration, and population scenarios for 195 countries and territories from 2017 to 2100: A forecasting analysis for the global burden of disease study. The Lancet, 396, 1285-1306. https://doi.org/10.1016/S0140-6736(20)30677-2.

von Braun, J., Teklu, T., \& Webb, P. (1999). Famine in Africa: Causes, responses, and prevention. Johns Hopkins University Press.

Wang, X., Yamauchi, F., Otsuka, K., \& Huang, J. (2014). Wage growth, landholding and machine services in China. Unpublished manuscript: Center for Chinese Agricultural Policy and the World Bank.

van Wart, J., van Bussel, L. G. J., Wolf, J., Licker, R., Grassini, P., Nelson, A., Boogaard, H., Gerber, J., Mueller, N. D., Claessens, L., van Ittersum, M. K., \& Cassman, K. G. (2013). Use of agroclimatic zones to upscale simulated crop yield potential. Field Crops Research, 143, 44-55. https://doi.org/10.1016/j.fcr.2012.11.023.

Weltin, M., Zasada, I., Franke, C., Piorr, A., Raggi, M., \& Viaggi, D. (2017). Analysing behavioural differences of farm households: An example of income diversification strategies based on European farm survey data. Land Use Policy, 62, 172-184. https://doi.org/ 10.1016/j.landusepol.2016.11.041.

Westphal, E. (1975). Agricultural systems in Ethiopia. Pudoc.

Willett, W., Rockström, J., Loken, B., Springmann, M., Lang, T., Vermeulen, S., Garnett, T., Tilman, D., DeClerck, F., Wood, A., Jonell, M., Clark, M., Gordon, L. J., Fanzo, J., Hawkes, C., Zurayk, R., Rivera, J. A., de Vries, W., Majele Sibanda, L., Afshin, A., Chaudhary, A., Herrero, M., Agustina, R., Branca, F., Lartey, A., Fan, S., Crona, B., Fox, E., Bignet, V., Troell, M., Lindahl, T., Singh, S., Cornell, S. E., Srinath Reddy, K., Narain, S., Nishtar, S., \& Murray, C. J. L. (2019). Food in the Anthropocene: The EAT-lancet commission on healthy diets from sustainable food systems. The Lancet, 393(10170), 447-492. https:// doi.org/10.1016/S0140-6736(18)31788-4.

World Bank (2020a). Poverty and shared prosperity 2020: Reversals of fortune. World Bank.

World Bank (2020b). World development indicators. World Bank. Available from https://data.worldbank.org/indicator.

Yamauchi, F. (2014). Wage growth, landholding, and mechanization in agriculture: evidence from Indonesia. The World Bank.

You, L., Ringler, C., Wood-Sichra, U., Robertson, R., Wood, S., Zhu, T., Nelson, G., Guo, Z., \& Sun, Y. (2011). What is the irrigation potential for Africa? A combined biophysical and socioeconomic approach. Food Policy, 36(6), 770-782. https://doi.org/10.1016/j. foodpol.2011.09.001.

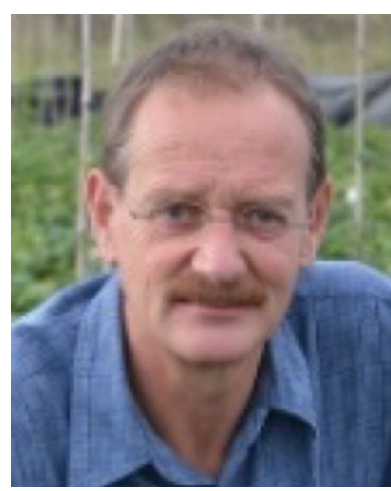

Ken Giller is Professor of Plant Production Systems at Wageningen University. Heleads a group of scientists with profound experience in applying systemsanalysisto explorefuture scenarios for land use with a focus on food production. Ken's research focuses on smallholder farming systems in sub-Saharan Africa, and in particular problems of soil fertility and the role of nitrogen fixation in tropical legumes, with emphasis on the temporal and spatial dynamics of resources within crop/livestock farming systems and their interactions. He is author of the standard text "Nitrogen Fixation in Tropical Cropping Systems" published in second edition in 2001. He is co-chair of the Thematic Network 7 on Sustainable Agriculture and Food Systems of the Sustainable Development Solutions Network (SDSN) of the United Nations andamember of the Unilever Sustainable Sourcing Advisory Board. Ken joined Wageningen University as Chair of Plant Production Systems in 2001 after holding professorships at Wye College, University of London, and the University of Zimbabwe.

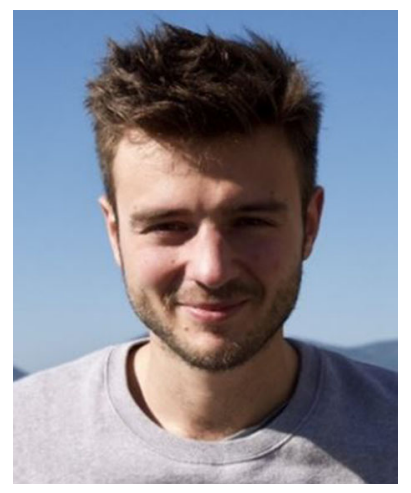

Thomas Delaune is a research assistant at the Plant Production Systemsgroup of Wageningen University. He recently graduated in agricultural sciences at the Ecole Superieure d'Agriculture in Angers, France and in crop sciences at Wageningen Unversity, Netherlands. With a strong interest in data analysis, geoinformation sciences, and statistics, his works currently focuses on the analysis of smallholder farming systems in subSharan Africa. He previously held a position of research assistant at the National Institute of Agricultural Research and Environment (INRAE) in France where his research focused on the relationships between crop pests and landscape composition.

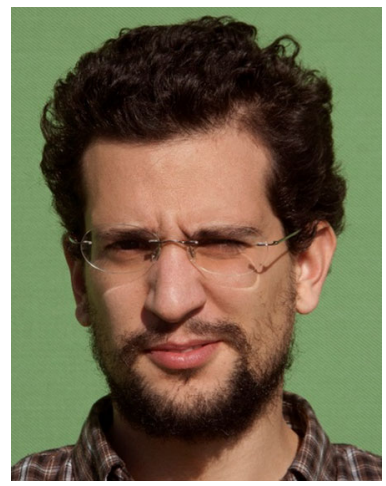

João Vasco Silva is systems agronomist at the International Maize and Wheat Improvement Center (CIMMYT) based in Harare, Zimbabwe and a guest researcher at the Plant Production Systems Group, Wageningen University (WU). João's expertise includes yield gap and resource use efficiency analysis, farming systems research and integrated assessments at field, farm, and regional levels. João holds a $\mathrm{PhD}$ from WU with a thesis focusing on explaining yield gaps at farm(ing) systems level including case studies on crop-livestock systems in Ethiopia, rice farming in the Philippines and arable farming in the Netherlands. This was followed by a post-doc at WU as part of a JPI- 
funded project aiming to identify opportunities for increasing water and nutrient use efficiencies in Europe and North Africa. João is currently involved in different research projects in East and Southern Africa focusing on guiding investments in acid soil management and on sustainable intensification of farming systems in the region.

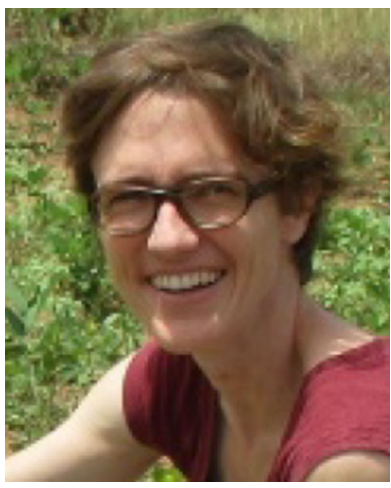

Katrien Descheemaeker is associate professor in the Plant Production Systems group of Wageningen University and Research (Netherlands). Her research focuses on farming systems analysis, soil-plant-animal interactions, and sustainable agricultural development, with a special interest in the functioning and dynamics of mixed crop-livestock systems. Current research combines experimental trial work with simulation modelling to identify and assess interventions for improved resource use efficiency and farm profitability, and reduced risks associated with climate and market variability. Across various projects on smallholder farming systems in sub-Saharan Africa, Dr. Descheemaeker and colleagues develop methods for participatory research with farmers and other stakeholders to increase the potential adoption and impact of technology and management options to increase farm productivity, food security and natural resource integrity.

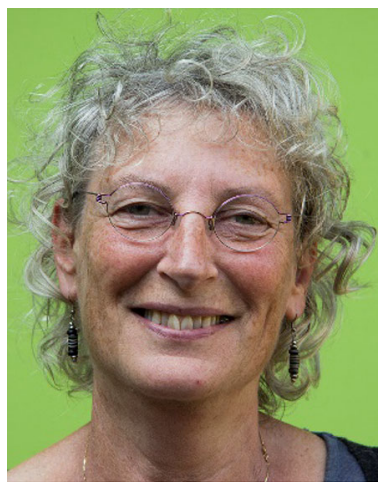

Gerrie van de Ven holds a PhD in Agricultural Science from Wageningen University. She is employed at the Plant Production Systems Group of that University. She combines research and teaching with a focus on farming systems analysis and optimization of land use systems related to all three dimensions of sustainability. Nutrient cycling, environmental impacts and indicators, the interaction between crops and livestock and economic consequences, both in the western world and in Africa, have her special attention. She previously worked at the Centre for Environmental Sciences at Leiden University and Plant Research International in Wageningen. Her scientific work has built on tools such as systems analysis and modelling approaches, mainly at the farm and regional level.

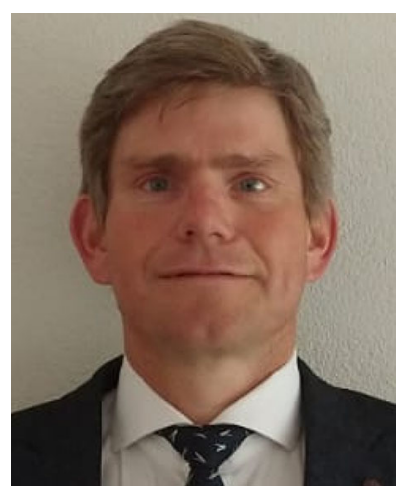

Antonius G.T. Schut (Tom) is associate professor at the Plant Production Systemsgroup of Wageningen University in the Netherlands. After a bachelor in dairy science he graduated as spatial soil scientist at the Wageningen University. Tom's research focusses on the optimization of agricultural systems with sustainable intensification, adapting farm management to local conditions to improve efficiency and minimise environmental impacts. His work combines analysis of farming systems with simulation of crop growth and nutrient flows for fields, farms and farming systems. Tom's current research focusses on better nutrient management with balanced fertilization to improve the productivity of farms in smallholder systems and improved circularity of agriculture with integrated crop and livestock systems in intensified farming systems.

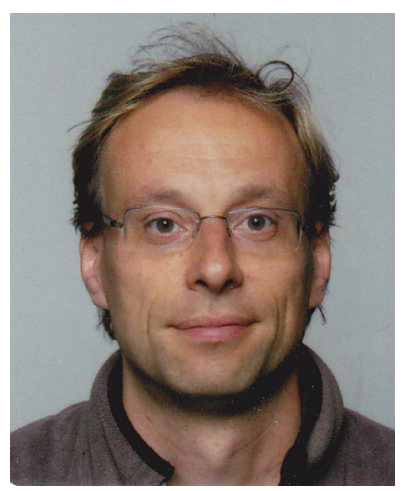

Mark van Wijk is a Senior Scientist at the International Livestock Research Institute, based in Quito, Ecuador. His research focuses on analysing farming systems in developing countries, trying to harvest the added value of combining modeling, experimental, participatory and statistical approaches. Recent work concentrated on developing tools to better target intervention options to improve income and diets of smallholder farmers, and quantify their adoption potential and observed effects. Previously he worked for almost 10 years as Assistant Professor at Wageningen University in the Plant Production Systems group.

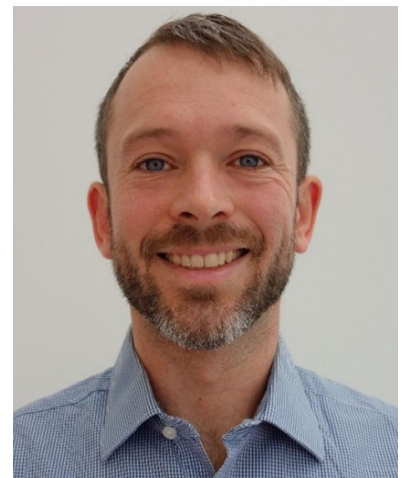

Jim Hammond is an interdisciplinary scientist working on agriculture and sustainability issues, at the International Livestock Research Centre. The main themes of his work are the creation of a global harmonised database on smallholder farming practices and development outcomes, the development of userfriendly research tools to nudge researcher behaviours towards best practices, and analyses of interactions between elements of the farm-household system and the contexts in which farmers operate. Other research interests include 
agricultural innovation, the role of personal motivations in technology adoption, poverty dynamics, and approaches to multi-variate visualisations. Jim co-leads the RHoMIS initiative (see www.rhomis. org), holds an honorary position at the University of Bristol, and sits on the editorial advisory board of the Agricultural Systems journal.

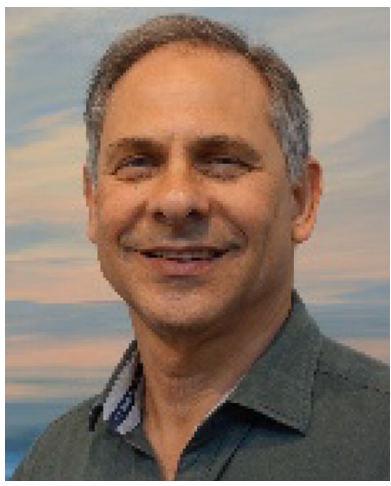

Dr. Zvi Hochman is a Chief Research Scientist in CSIRO Agriculture and Food. He is a systems agronomist with expertise in exploring productivity frontiers in rain fed cropping systems at field to national scales and in managing climate-related crop production risk. He is currently researching: 1. How to best quantify, map and diagnose the causes of the gap between actual and potential yields of individual crops and cropping systems in Australia's rain-fed environments; 2 . Farm level adaptation of cropping systems to a variable and changing climate; and 3. Crop yield forecasting at multiple scales.

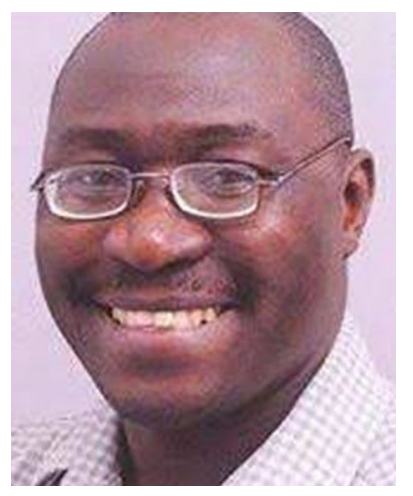

Godfrey Taulya is Associate Scientist at the International Institute of Tropical Agriculture (http://www.iita.org/) which is part of the Consortium of International Agricultural Research Centers or CGIAR (https://www.cgiar.org/). Godfrey Taulya completed a PhD from Wageningen University's Plant Production Systems Group in 2015 on Banana Agronomy. His research focusses on soil-plantatmosphere interactions and resource use efficiency at field to farm scale. Godfrey has interest in managing crop nutrition and water requirements for productivity and the associated sustainable intensification practices (https://scholar.google.com/citations? user= $\mathrm{n} 4 \mathrm{gFe} 40 \mathrm{AAAAJhl}=\mathrm{en}$ ). His current activities combine experimental trials with nuanced scaling of promising options for sustainable intensification through multi-institutional and multi-actor partnerships. $\mathrm{He}$ is a Co-PI on 'Improving scalable banana agronomy for small scale farmers in highland banana cropping systems in East Africa' (https:// www.iita.org/iita-project/improving-scalable-banana-agronomy/) led by the National Agricultural Research Organization (https://naro.go.ug/) with funding from the Bill and Melinda Gates Foundation. Godfrey also coordinates the Sustainable Intensification/Diversification Cluster under the Flagship Project on Improved Livelihoods at Scale (https:// www.rtb.cgiar.org/research-areas/improved-livelihoods-at-scale/) of the CGIAR Crops Research Project on Roots Tubers and Bananas.

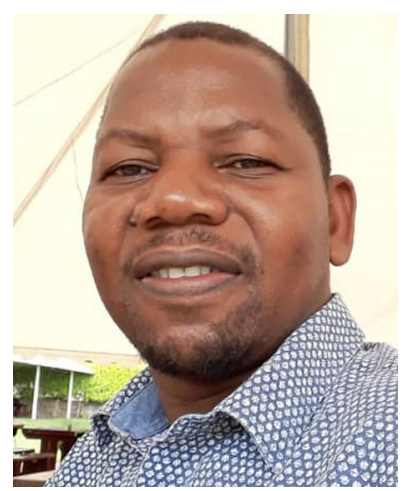

Regis Chikowo is an Associate Professor of Agronomy at University of Zimbabwe and Assistant Professor at Michigan State University, Plant Soil and Microbial Sciences Department. His interests are in agricultural technology development, delivery and use by smallholder farmers. He has over the years carried out basic and applied research on nutrient management on smallholder farms in southern Africa. Approaches that integrate legumes to tap into biological $\mathrm{N}_{2-}$ fixation to sustain production on smallholder farms have been core his investigations. He currently invests much of his time leading the implementation of the Africa Research in Sustainable Intensification for the Next Generation (Africa RISING) project in Malawi, a Feed the Future collaborative effort between MSU and the International Institute of Tropical Agriculture (IITA); and the Dynamics of Soil Carbon Sequestration in Tropical and Temperate Agricultural systems (DSCATT) project, jointly implemented by the University of Zimbabwe and CIRAD.

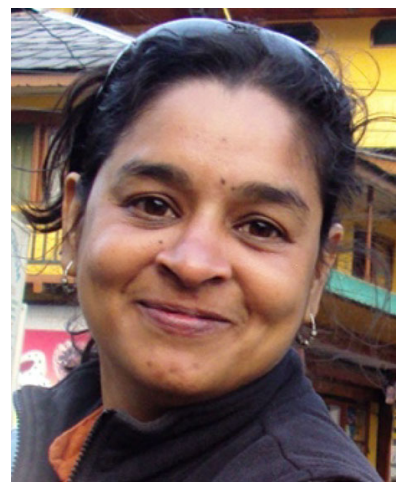

Sudha Narayanan is a Research Fellow, International Food Policy Research Institute (IFPRI), New Delhi. Sudha's research interests straddle agriculture, food and nutrition policy, and human development in India. She is particularly interested in survey-based research using microeconometric approaches to understand broader questions of agrarian change and state delivery systems for nutrition security. Narayanan holds a $\mathrm{PhD}$ in agricultural economics from Cornell University and MPhil and M.A. degrees in economics from the Delhi School of Economics, India.

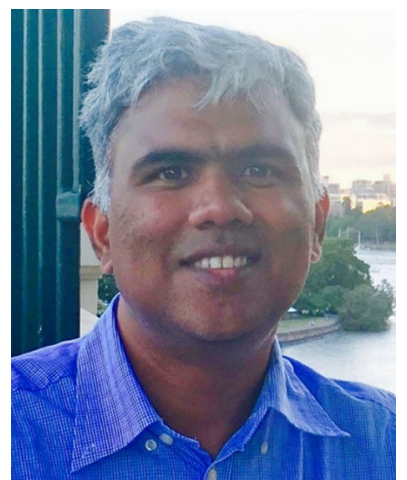

Avinash Kishore is a Research Fellow in the New Delhi Office of the International Food Policy Research Institute (IFPRI). His research focuses on understanding how public policies and markets affect the adoption [and nonadoption] of sustainable technologies and practices in agriculture (e.g., solar pumps, soil health cards, soil micro-nutrients, improved seeds) in South Asia. He is also interested in understanding the impact of India's food policies and large food safety-net programs on farmers and consumers. Currently, he leads research projects 
on understanding food systems in Bangladesh, India, and Nepal; linkages between agriculture and nutrition in eastern India, and the policy research component of the Cereals Systems Initiative for South Asia (CSISA) - a program implemented jointly by CIMMYT, IFPRI, and IRRI. Avinash studied Rural Management at IRMA and Public Policy at Princeton and Harvard.

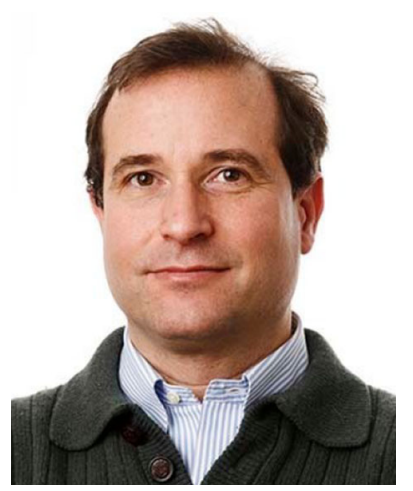

Fabrizio Bresciani is the Lead Regional Economist for IFAD's Latin American and Caribbean division. He joined IFAD in 2014 as the Lead Regional Economist in the Asia and Pacific Division. His main areas of interest include rural transformation, food security, inclusive and sustainable models of value chain development, and digital transformation of agriculture. He leads IFAD's grant program in Latin America and the Caribbean and is responsible for coordinating the knowledge and innovation partnerships in the region. He has previously served at the World Bank as a Senior Agricultural Economist and Agriculture Sector Coordinator in Indonesia (2011-2014) and as a Rural Development Economist in the Philippines (2007-2011). Before joining the World Bank, Fabrizio Bresciani worked as an Economist at the Agricultural Development Economics Division of the Food and Agriculture Organization of the United Nations in Rome (2001-2007) and at the World Bank's Development Economics Research Group (1998-2001). He holds a PhD in Agricultural and Natural Resource Economics from the University of Maryland, College Park, and a MSc in Environmental and Natural Resource Economics from the Universidad de Los Andes, Colombia.

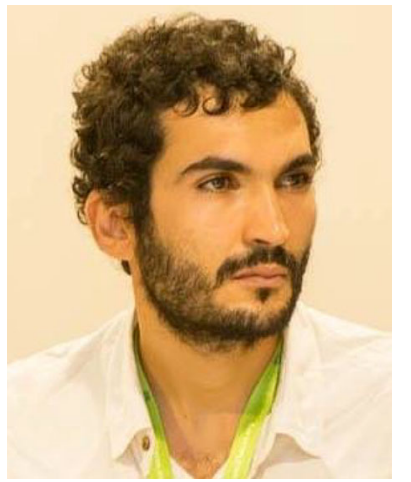

Heitor Mancini Teixeira currently works as a post-doc at the Plant Production Systems and Farming Systems Ecology groups, at Wageningen University. He has been working with research, extension and education since 2009 with the goal to understand, design and implement sustainable and multi-functional farming systems. His main research focuses on the links among biodiversity, ecosystem services and social actors. He takes a strong participatory and interdisciplinary approach, focusing on the interaction with other researchers and stakeholders and on the use of social and ecological scientific methods. Heitor is a Forest engineer graduated at the Federal University of Viçosa and has a $\mathrm{PhD}$ in Plant and Soil science from Wageningen University and Federal University of Viçosa.

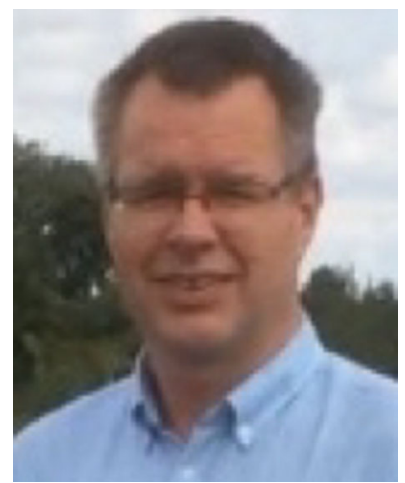

Jens A. Andersson is research fellow at the Plant Production Systemsgroup of Wageningen University. Trained as a rural development sociologist / social anthropologist, Jens' research focuses on technology adoption and its social (equity) impacts, ruralurban linkages and rural livelihood diversification, the development of decision support tools for smallholder farmers, and agricultural change in smallholder farming systems in Africa. He has worked extensively in southern Africa, and held positions at the International Maize and Wheat Improvement Center (CIMMYT), the University of Amsterdam, and was affiliated to the University of the Witwatersrand, the University of Malawi, and the University of Zimbabwe.

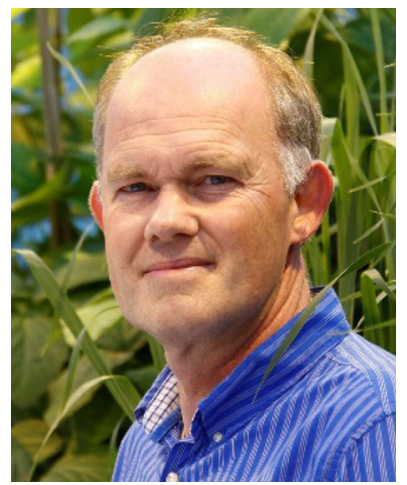

Martin van Ittersum holds a $\mathrm{PhD}$ in Agricultural and Environmental Science from Wageningen University. He is a professor at the Plant Production Systems group of the same university. His research and teaching focus on research concepts and methods for the analysis, design and integrated assessment of agricultural systems from field to farm, regional and global level. He has led and is leading a large number of (inter)national projects dealing with global food availability, integrated assessment of agricultural systems, yield gap analysis, phosphorus scarcity, climate change and circular food systems. He was the co-chair of the 1st and 4th editions of the International Conference on Global Food Security. In 2015 and 2016 he was the interim chair of the Farming Systems Ecology group at Wageningen University. He was nominated a highly-cited researcher from 2015 to 2020 and has (co)authored ca. 200 papers in international scientific journals. 


\section{Affiliations}

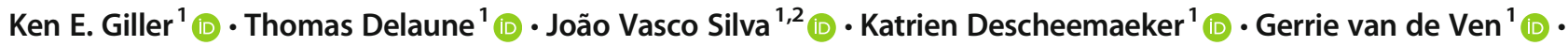
Antonius G.T. Schut ${ }^{1}$ (D) - Mark van Wijk ${ }^{3}$ (D) - James Hammond ${ }^{3}$ (D) - Zvi Hochman ${ }^{4}$ (D) - Godfrey Taulya ${ }^{5}$ (D) Regis Chikowo ${ }^{6}$ (D) Sudha Narayanan ${ }^{7}$ (D) $\cdot$ Avinash Kishore $^{7}$ (D) $\cdot$ Fabrizio Bresciani ${ }^{8}$ (D) $\cdot$ Heitor Mancini Teixeira ${ }^{1}$ (D) $\cdot$ Jens A. Andersson ${ }^{1}$ (D) - Martin K. van Ittersum ${ }^{1}$ (D)

1 Plant Production Systems, Wageningen University, POBox 430, 6700AK, Wageningen, The Netherlands

2 International Maize and Wheat Improvement Center (CIMMYT), $12.5 \mathrm{~km}$ peg Mazowe Road, Harare, Zimbabwe

3 International Livestock Research Institute (ILRI), Box 30709 , Nairobi, PO 00100, Kenya

4 CSIRO Agriculture \& Food, 306 Carmody Road, St Lucia, QLD 4067, Australia
5 International Institute of Tropical Agriculture, POBox 7878, Kampala, Uganda

6 Crop Science Department, University of Zimbabwe, Harare, Zimbabwe

7 International Food Policy Research Institute (IFPRI), South Asian Region, Block C, NASC Complex, DPS Marg, Opposite Todapur, Pusa, New Delhi 110012, India

8 IFAD, Asia and Pacific Division, Via Paolo di Dono, 42 Rome, Italy 